\title{
Glutamate Receptor Agonists Stimulate Diverse Calcium Responses in Different Types of Cultured Rat Cortical Glial Cells
}

\author{
James A. Holzwarth, ${ }^{1}$ Simon J. Gibbons, ${ }^{1}$ James R. Brorson, ${ }^{2}$ Louis H. Philipson, ${ }^{3}$ and Richard J. Miller ${ }^{1}$ \\ ${ }^{1}$ Department of Pharmacological and Physiological Sciences, ${ }^{2}$ Department of Neurology and ${ }^{3}$ Department of Medicine, \\ The University of Chicago, Chicago, Illinois 60637
}

We examined the effects of different types of glutamate receptor agonists on the intracellular calcium concentration, $\left(\left[\mathrm{Ca}^{2+}\right]_{i}\right)$, in cultured rat cortical glial cells. The cells in these cultures were characterized immunocytochemically using antlbodies against glial fibrillary acidic protein, $A_{2} B_{5}$, and $O X$ 42. The metabotropic glutamate receptor agonist $(1 S, 3 R)$ 1-aminocyclopentane-1,3-dicarboxylic acid produced $\mathrm{Ca}^{2+}$ mobilization from intracellular stores in all classes of cells. Agonists at non-NMDA glutamate receptors also produced large increases in $\left[\mathrm{Ca}^{2+}\right]_{i}$, primarily in cells of the O-2A lineage. Disruption of intracellular $\mathrm{Ca}^{2+}$ stores with thapsigargin showed that increases in $\left[\mathrm{Ca}^{2+}\right]$, produced by activating AMPA/kainate receptors were primarily due to $\mathrm{Ca}^{2+}$ influx rather than $\mathrm{Ca}^{2+}$-induced $\mathrm{Ca}^{2+}$ release. Agonists at NMDA receptors were ineffective.

Electrophysiological studies revealed that cells of the 0-2A lineage exhibited moderate inward currents in response to kainate in $\mathrm{Na}^{+}$-containing solutions, but only small inward currents and outward rectification in $\mathrm{Na}^{+}$-free solutions. However, in the presence of cyclothiazide, the kainate-induced currents were increased in size and a rightward shift of the reversal potential with increased $\left[\mathrm{Ca}^{2+}\right]_{0}$ could be demonstrated. Activation of cells by kainate, but not by depolarizing stimuli, stimulated the uptake of $\mathrm{Co}^{2+}$. Polymerase chain reaction studies showed that the glutamate receptor subunits GluR1-4 and GluR6 were all expressed in these cultures, but GluR5 was absent.

The nature of the $\mathrm{Ca}^{2+}$ uptake pathway activated by nonNMDA receptor agonists in the $0-2 A$ lineage population is discussed. It is considered most likely that the 0-2A lineage cells express both non-NMDA receptors that are relatively impermeable to divalent cations, as well as a smaller population that are $\mathrm{Ca}^{2+}$ permeable.

[Key words: kainate, $\mathrm{Ca}^{2+}$-permeable glutamate receptor, O-2A progenitors, astrocytes, AMPA]

Recent clcctrophysiological, pharmacological, and molecular biological studies have demonstrated the existence of multiple types of glutamate receptors (Henneberry, 1992). These recep-

Received March 17, 1993; revised Aug. 18, 1993; accepted Sept. 29, 1993.

This work is supported by U.S. Public Health Service Grants DA-02121, DA02575, and MH-40165 to R.J.M., Grant T32 GM 07151 to J.A.H., long-term postdoctoral fellowship from Human Frontier Science Program to S.J.G., an American Diabetes Association Research and Development Award to L.H.P., a grant from the Marilyn M. Simpson Charitable Trust (L.H.P.), and a Howard Hughes Medical Institute Physician Research Fellowship to J.R.B.

Correspondence should be addressed to Richard J. Miller, Department of Pharmacological and Physiological Sciences, The University of Chicago, 947 East 58th Street, Chicago, IL 60637.

Copyright @ 1994 Society for Neuroscience $0270-6474 / 94 / 141879-13 \$ 05.00 / 0$ tors can be grouped into two major categories: ligand-gated ion channels (ionotropic) (Miller, 1991a) and G-protein linked (metabotropic) (Miller, 1991b). Stimulation of these receptors leads to the activation of several second messenger systems. $\mathrm{Ca}^{2+}$, in particular, has been shown to play a major role in glutamate receptor-mediated signal transduction under several different circumstances, including the regulation of synaptic plasticity, excitotoxicity, and neuronal excitability (Mayer and Miller, 1990).

In addition to their presence on neurons, glutamate receptors have also been found on glial cells both in brain slices (Berger et al., 1992; Fulton et al., 1992) and in culture (Sontheimer et al., 1988; Usowicz et al., 1989; Wyllie et al., 1991). In general, the functions of these glial receptors are unclear but their activation can produce long-range signaling events in cultures of glia (Cornell-Bell et al., 1990a; Glaum et al., 1990; Jensen and Chiu, 1990, 1991) or of brain slices (Dani et al., 1992). In previous studies, both metabotropic (Milani et al., 1989; Ahmed et al., 1990; Glaum et al., 1990; Barry et al., 1991; Jensen and Chiu, 1991, 1993; Schwartz, 1993) and ionotropic (Sontheimer ct al., 1988; Backus et al., 1989; Enkvist et al., 1989; Usowicz et al., 1989; Jensen and Chiu, 1990, 1991, 1993; Wyllie et al., 1991; Clark and Mobbs, 1992; Matute et al., 1993) types of glutamate receptors have been identified on glial cells. The former receptors can stimulate $\mathrm{Ca}^{2+}$ mobilization from intracellular stores (Glaum et al., 1990; Yuzaki and Mikoshiba, 1992), whereas the latter can activate $\mathrm{Ca}^{2+}$ influx by a variety of routes (Glaum et al., 1990; Jensen and Chiu, 1990, 1991). For example, some types of ionotropic glutamate receptors exhibit an appreciable permeability to $\mathrm{Ca}^{2+}$ (Iino et al., 1990; Hollman et al., 1991; Burnashev et al., 1992a; Egebjerg and Heinemann, 1993), whereas others are relatively impermeable to $\mathrm{Ca}^{2+}$ and only produce influx through voltage-sensitive $\mathrm{Ca}^{2+}$ channels subsequent to cell depolarization (Miller, 1991a).

In general, the distribution of glutamate receptors on different classes of glia have been incompletely defined. Several groups have reported that ionotropic glutamate agonists can produce changes in the membrane potential of glial cells (Bowman and Kimelberg, 1984; Sontheimer et al., 1988; Backus et al., 1989; Enkvist et al., 1989; Usowicz et al., 1989; Clark and Mobbs, 1992), including type 2 astrocytes and their progenitors (Usowicz et al., 1989; Gallo et al., 1992; Stephens et al., 1993), suspensions of primary astrocytes (Enkvist et al., 1989), and glial cells in slices (Berger ct al., 1992). However, some of these effects may be due to the electrogenic uptake of glutamate (Wyllie et al., 1991; Stephens et al., 1993). In the case of the Bergmann glia of the cerebellum, glutamate receptor agonists increase $\left[\mathrm{Ca}^{2+}\right]_{i}$ primarily by activating $\mathrm{Ca}^{2+}$ influx directly through $\mathrm{Ca}^{2+}$-permeable AMPA/kainate receptors (Burnashev et al., 1992a; Müller 
A

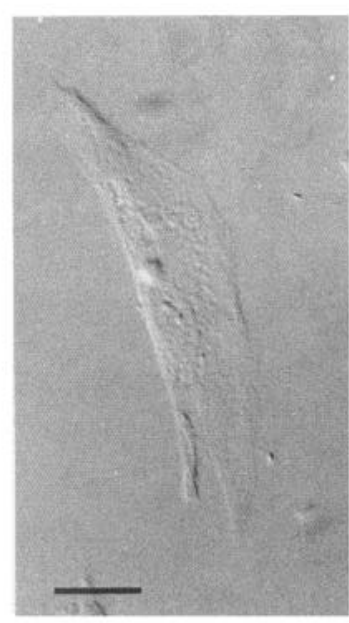

Nom

B

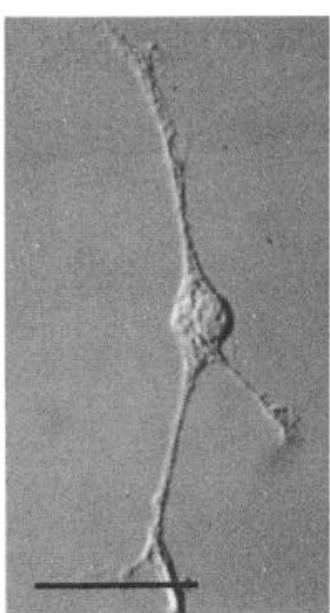

Nom

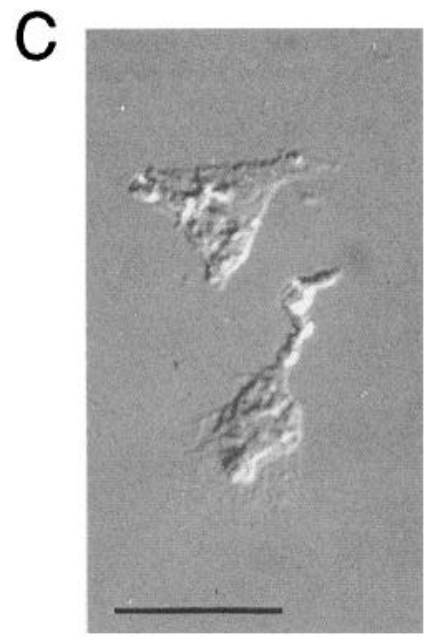

Nom

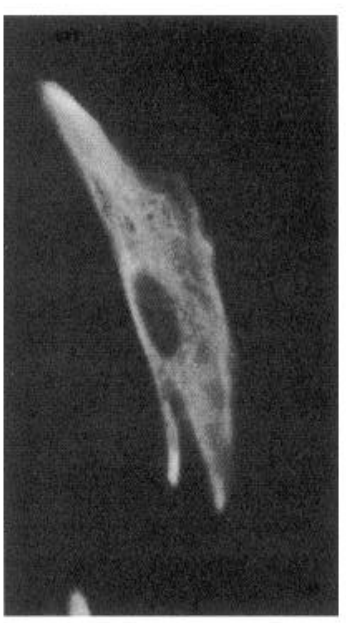

GFAP

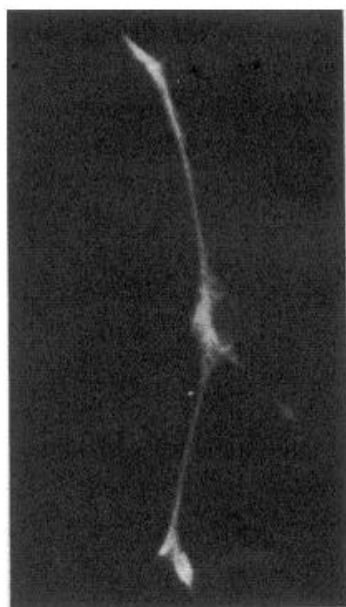

GFAP

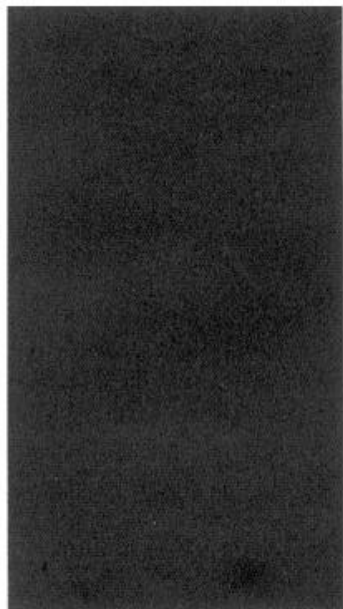

GFAP

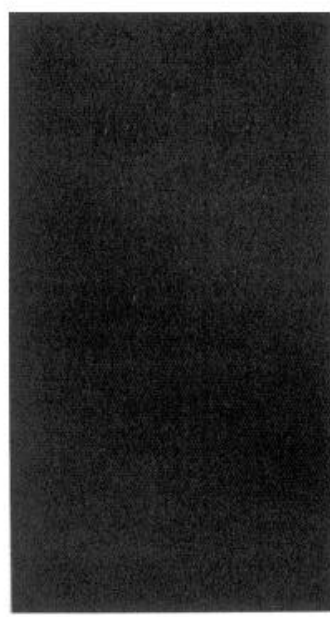

$A_{2} B_{5}$

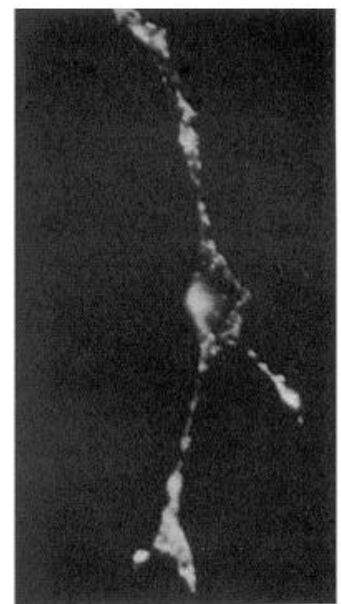

$\mathrm{A}_{2} \mathrm{~B}_{5}$

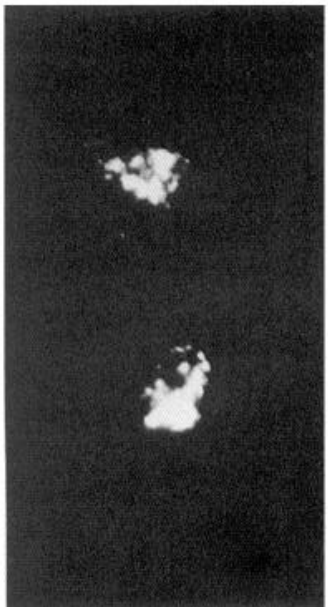

$0 x-42$ AMCA were blank. Scale bar, $20 \mu \mathrm{m}$. 
et al., 1992). This pathway for $\mathrm{Ca}^{2+}$ influx may also exist in other types of glia from the brain (Enkvist et al., 1989; Glaum et al., 1990; Jensen and Chiu, 1990, 1991; Pruss et al., 1991). However, whether it exists on all types of glial cells is unknown. We have therefore examined the $\left[\mathrm{Ca}^{2+}\right]_{i}$ response to different types of glutamate receptor agonists in cultures of cortical glia that contain a variety of cell types. The data indicate a differential localization of some types of glutamate receptors on different types of glia, leading to diverse mechanisms of $\left[\mathrm{Ca}^{2+}\right]_{i}$ regulation.

\section{Materials and Methods}

\section{Cell culture}

Cells were cultured from 1-3-d-old rat pup cortices, as a modification of the procedure in Holzwarth et al. (1992), briefly as follows. Cortices were removed under sterile conditions, hippocampi discarded, and cortices minced with scalpel blade to $1 \mathrm{~mm}$ pieces. The tissue was then incubated with $0.25 \%$ trypsin in Hank's balanced salt solution (HBSS) at $37^{\circ} \mathrm{C}$ for $20-25 \mathrm{~min}$ for digestion of extracellular matrix. Then DNase $(1.5 \mathrm{mg}+2.5 \mathrm{mg} \mathrm{MgCl}$ in $1 \mathrm{ml}$ HBSS) was added and the tissue was triturated nine times with a sterile Pasteur pipette. The tissue was incubated a further $2 \mathrm{~min}$ at room temperature and then triturated until no clumps of tissue were visible. Dulbecco's Modified Eagle's Medium (DMEM) $(10 \mathrm{ml})$ with $10 \%$ fetal calf serum (FCS) was added. The tissue was allowed to settle for $4-5 \mathrm{~min}$ and $16 \mathrm{ml}$ of the supernatant was decanted to anothęr tube, which was centrifuged at $150 \times g$ for $5 \mathrm{~min}$. The supernatant was discarded, the pellet resuspended in HBSS, and the cells plated onto $60 \mathrm{~mm}$ tissue culture dishes with $10 \mathrm{ml}$ of $10 \%$ FCS. The next day the $10 \%$ FCS was removed, the plates were washed with HBSS, and DMEM with $10 \%$ horse serum (10\% HS) was added. The cclls were grown to confluency (after about a week) and were replated, to avoid nonglial contamination, in the following manner. The cells were incubated with $0.25 \%$ trypsin HBSS for $10 \mathrm{~min}$. The plate was then washed with $10 \%$ HS and the lavage centrifuged at $150 \times g$ for $5 \mathrm{~min}$. The supernatant was discarded and the pellet resuspended in HBSS. The resuspended cells were then plated onto round $15 \mathrm{~mm}$ glass coverslips and 10\% HS was added. The cultured glia were used after $1-3$ weeks in culture, or until the cells were too confluent to allow identification of individual cells.

\section{Immunocytochemistry}

The following solutions were used for immunocytochemical experiments-basal buffer (BB): $\mathrm{CaCl}_{2} 2 \mathrm{~mm}, \mathrm{NaCl} 155 \mathrm{~mm}$, HEPES $10 \mathrm{~mm}$, pH 7.4; BB with blocker (BB blockcr): $\mathrm{BB}$ with $2 \%$ bovine serum albumin (BSA); phosphate-buffered saline (PBS): $\mathrm{NaCl} 155 \mathrm{mM}, \mathrm{NaH}_{2} \mathrm{PO}_{4}$ and $\mathrm{Na}_{2} \mathrm{HPO}_{4} 20 \mathrm{~mm}$ to make pH 7.4; permeabilizing PBS with blocker (PPBS): PBS with $2 \%$ BSA and $0.05 \%$ Tween-20 (Calbiochem).

The antibodies $A_{2} B_{5}$ and $O X-42$ were incubated on live cells and the cells were fixed after washing the secondary antibody. For these antibodies, BB blocker was used, except for the washing immediately before the fixing step, where BB was used. The antibodies against glial fibrillary acidic protein (GFAP) and neurofilament were incubated with fixed permeabilized cells. For these antibodies, PPBS was used throughout the experiment.

Fixation. After incubation with $\mathrm{A}_{2} \mathrm{~B}_{3}$ or $\mathrm{OX}-42$ and the secondary antibody, acid alcohol ( $5 \%$ glacial acetic acid in $95 \%$ ethanol) was used for $10 \mathrm{~min}$ at $-20^{\circ} \mathrm{C}$. For single staining experiments with GFAP, synaptophysin, and neurofilament, acetone for $10 \mathrm{~min}$ at $-20^{\circ} \mathrm{C}$ was used. For double stain experiments, acid alcohol was used before GFAP staining.

Prior to fixing, the coverslips were washed with solutions without blocker. Washing consisted of a $1 \mathrm{hr}$ incubation in $2 \mathrm{ml}$ of solution with three changes of solution at 15 min intervals. After fixing, we used a $15 \mathrm{~min}$ incubation in solution not containing blocker $(2 \mathrm{ml})$ and changed solution three times.

Prior to antibody incubations, coverslips were washed with solutions containing blocker, which also served as the diluent for the antibodies. Immediately after antibody incubations, the antibody was quickly removed, then $200 \mu \mathrm{l}$ of solution was added and aspirated.

The cells and antibodies were incubated together at room temperature for $30 \mathrm{~min}$.
Antibodies. Antibodies used were the following: $\mathrm{A}_{2} \mathrm{~B}_{5}$ (Boehringer Mannheim Biochemicals), used at $10 \mu \mathrm{g} / \mathrm{ml} ; \mathrm{OX}-42$ (Accurate Chemicals), ascites used at 1:100 dilution; GFAP (Dako), prediluted; neurofilament (clone NR4, Boehringer-Mannheim Biochemicals), diluted 1:4; synaptophysin (Dako), used at 1:50 dilution.

Secondary antibodies. The secondary antibodies were, for counting, biotinylated anti-rabbit or anti-mouse (Vector Labs), diluted as per instructions; for double staining and imaging, Texas red conjugated antimouse (Jackson ImmunoResearch), diluted 1:40, and aminomethylcoumarin acetate (AMCA)-conjugated anti-rabbit (Jackson ImmunoResearch), diluted 1:40.

\section{Fura-2 microfluorimetry}

Cells were incubated in a solution containing fura- 2 acetoxy methyl ester (fura-2 AM; $5 \mu \mathrm{M}$ ) for $30 \mathrm{~min}$ at $37^{\circ} \mathrm{C}$ in a buffered solution containing (in mu) $\mathrm{NaCl} 143, \mathrm{KCl} 3, \mathrm{CaCl}_{2} 2, \mathrm{MgCl}_{2} 1$, HEPES 10 , glucose $10 ; \mathrm{pH}$ was adjusted to 7.4 with $\mathrm{NaOH}$. Cells were then rinsed and incubated for a further $30 \mathrm{~min}$ at $37^{\circ} \mathrm{C}$ in a fura-2-free solution. Fura-2 fluorescence was determined as previously described (Thayer et al., 1988). Background fluorescence was measured from a cell-free region of the coverslip. Solutions were at $\mathrm{pH} 7.4$ and had the following compositions (in mM)-Na-containing: $\mathrm{NaCl} 137, \mathrm{KCl} 3$ or $5, \mathrm{CaCl}_{2} 2, \mathrm{MgCl}_{2}$ 1, HEPES 10, and glucosc 10; $\mathrm{Na}$-frec/ $\mathrm{N}$-methyl-D-glucaminc (NMDG): NMDG $137, \mathrm{KCl} 3$ or $5, \mathrm{CaCl}_{2} 2, \mathrm{MgCl}_{2} 1, \mathrm{HEPES} 10$, and glucose 10 ; Ca-free/Co-containing: $\mathrm{NaCl} 137, \mathrm{KCl} 5, \mathrm{CoCl}_{2} 2, \mathrm{MgCl}_{2}$ 1, HEPES 10,

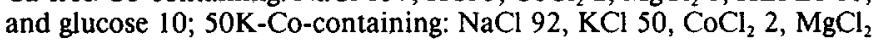
1, HEPES 10, and glucose 10.

\section{Fura-2 digital imaging}

Digital fluorescent microscopy was used to determine the correlation between the pharmacology of excitatory amino acid agonist-evoked rises in $\left[\mathrm{Ca}^{2+}\right]_{i}$ and immunocytochemical staining. Gridded coverslips containing cortical glial cells were washed twice with HEPES-buffered Hank's balanced salt solution [HHBSS; $\mathrm{pH} 7.45$, which contained (in mM) $\mathrm{NaCl}, 137 ; \mathrm{KCl}, 5 ; \mathrm{MgSO}_{4}, 0.41 ; \mathrm{MgCl}_{2}, 0.49 ; \mathrm{CaCl}_{2}, 2 ; \mathrm{KH}_{2} \mathrm{PO}_{4}$ $7 \mathrm{H}_{2} \mathrm{O}, 0.64, \mathrm{NaHCO}_{3}, 3$; glucose, 5.5; HEPES, 20] and were loaded with fura-2 in HHBSS as described for microfluorimetry experiments. Loading and completeness of deesterification were judged by stable fluorescence ratios and by ensuing adequate emitted fluorescence throughout the experiment for both 340 and $380 \mathrm{~nm}$ excitation wavelengths. Coverslips were mounted in a laminar flow chamber (flow rate, $2-3 \mathrm{ml} / \mathrm{min}$ ) over an inverted stage fluorescent microscope (Nikon) and continuously perfused with HHBSS. All drugs were dissolved and delivered in the perfusate. Cells were alternately illuminated with $340 /$ $380 \mathrm{~nm}$ light from a mercury source (Oriel). Emitted light was passed through a 480 barrier filter into a KS1380 image intensifier coupled to a Dage model 70 vidicon camera. Images were digitized as $256 \times 256$ pixel $\times$ eight bit arrays by an IBM PC-AT driven Magiscan system (Joyce Loebl, Garden City, NY). Ratios of sequential 340/380 nm excitation image pairs were calculated and compared to a standard curve for free $\left[\mathrm{Ca}^{2+}\right]$ constructed from shallow solutions of known $\mathrm{Ca}^{2+}$ and fura- 2 concentration, as previously described for this apparatus (Byron and Villereal, 1989). Numerical values reported are an average of $>50$ adjacent pixels. Exposure time for each wavelength was $500-750 \mathrm{msec}$, with cells exposed to UV light only during data collection. Because of the long periods of data acquisition used to produce a ratioed image $(1.5-3 \mathrm{sec})$, we probably underestimated the peak amplitude of the change in $\left[\mathrm{Ca}^{2+}\right]$, in these experiments.

For the $\mathrm{Ca}^{2+}$-free experiments, $\mathrm{Ca}^{2+}$ was omitted and 0.1 mM EGTA added to the HHBSS. Cells were perfused with $\mathrm{Ca}^{2+}$-free HHBSS for 2 min prior to agonist application. This treatment has been previously shown in our laboratory to block $\left[\mathrm{Ca}^{2+}\right]_{l}$, responses to depolarizing stimuli in neuronal cultures and to kainate (KA) in glial cultures. Where $\mathrm{Na}^{+}$-free solutions were required, $\mathrm{Na}^{+}$was replaced with equimolar quantities of $N$-methyl-D-glucamine and the $\mathrm{pH}$ adjusted with $\mathrm{HCl}$. The size of $\left[\mathrm{Ca}^{2+}\right]_{i}$ rises was calculated from the initial peak obtained with agonist treatment. As with $\mathrm{Ca}^{2+}$-free solutions, $\mathrm{Na}^{+}$-free solutions were perfused for $2 \mathrm{~min}$ before addition of agonist. In some experiments, a rise in $\left[\mathrm{Ca}^{2+}\right]$, was obtained with $\mathrm{Na}^{+}$-free solutions per se; unless the $\left[\mathrm{Ca}^{2+}\right]_{i}$ returned to baseline, these experiments were not included in the data analysis.

For some experiments $\left[\mathrm{Ca}^{2+}\right]_{i}$ was imaged using a Hamamatsu intensified CCD camera coupled to a Nikon microscope and a 486 computer-based acquisition system from Universal Imaging. 
A

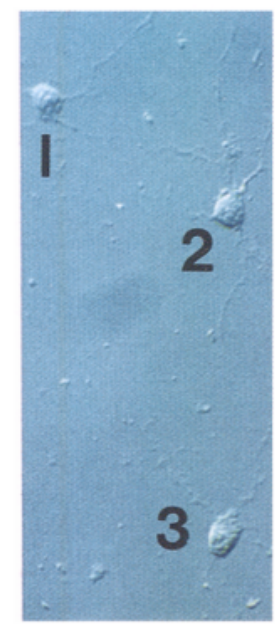

Nom

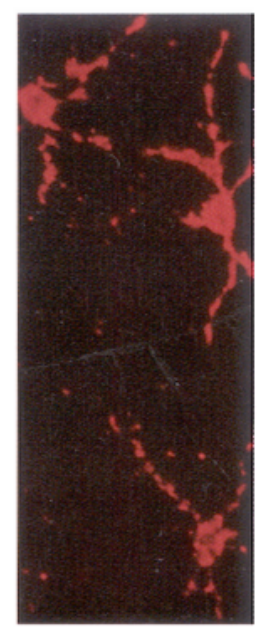

$A_{2} B_{5}$

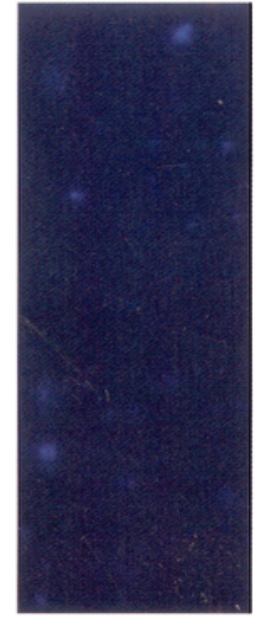

GFAP

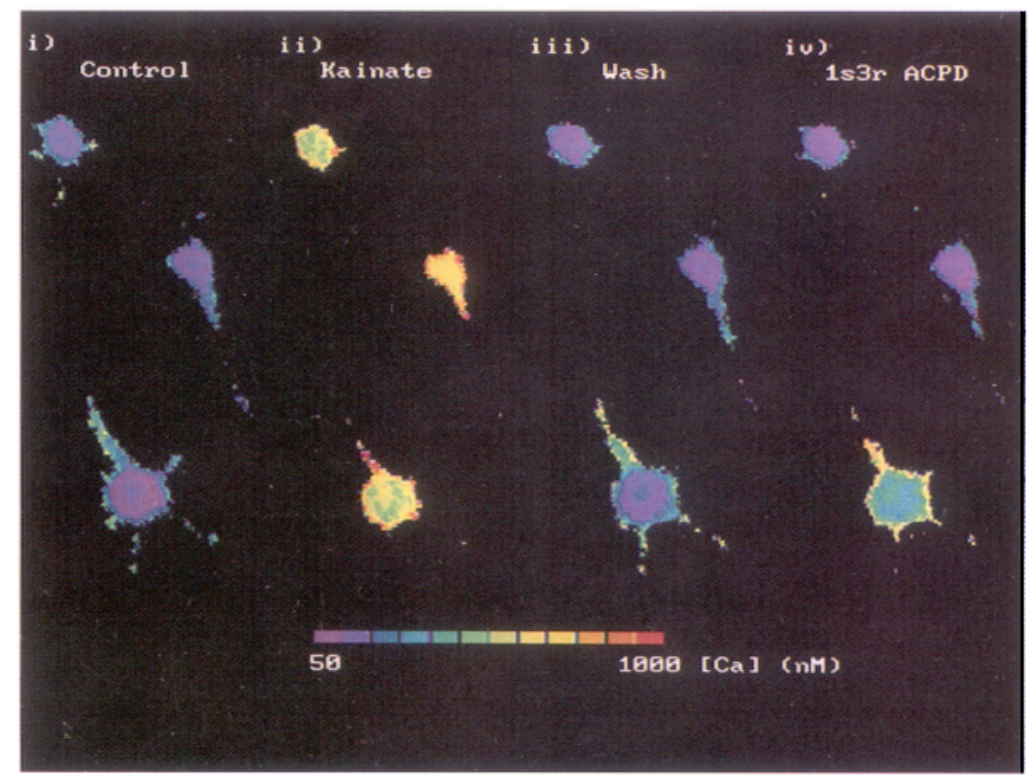

Cell 1

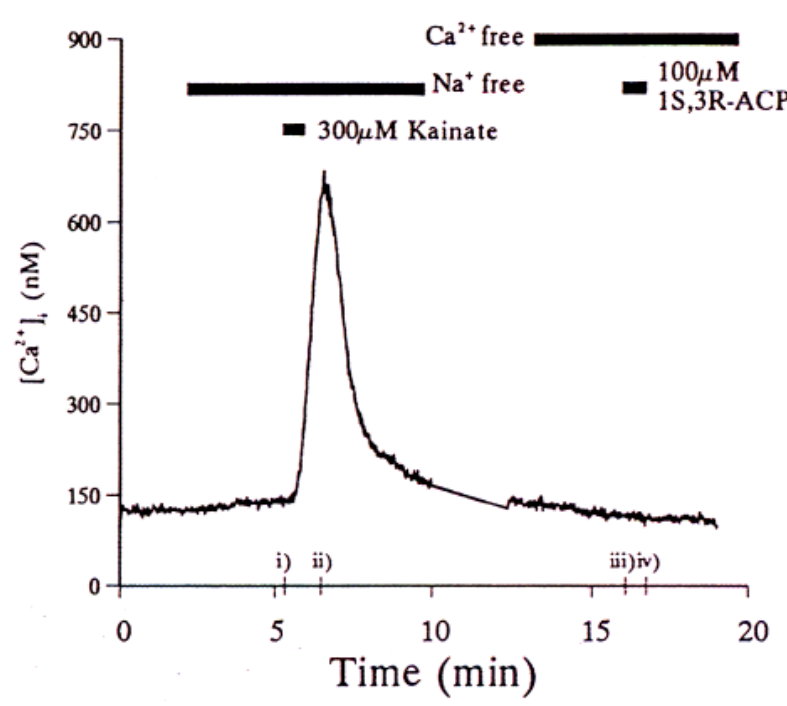

Cell 2

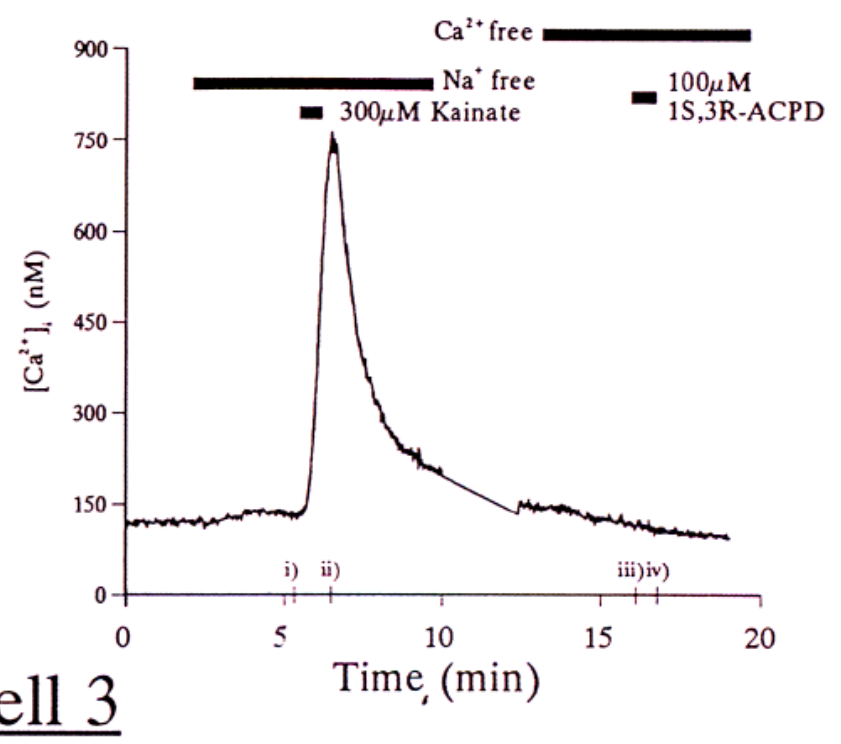

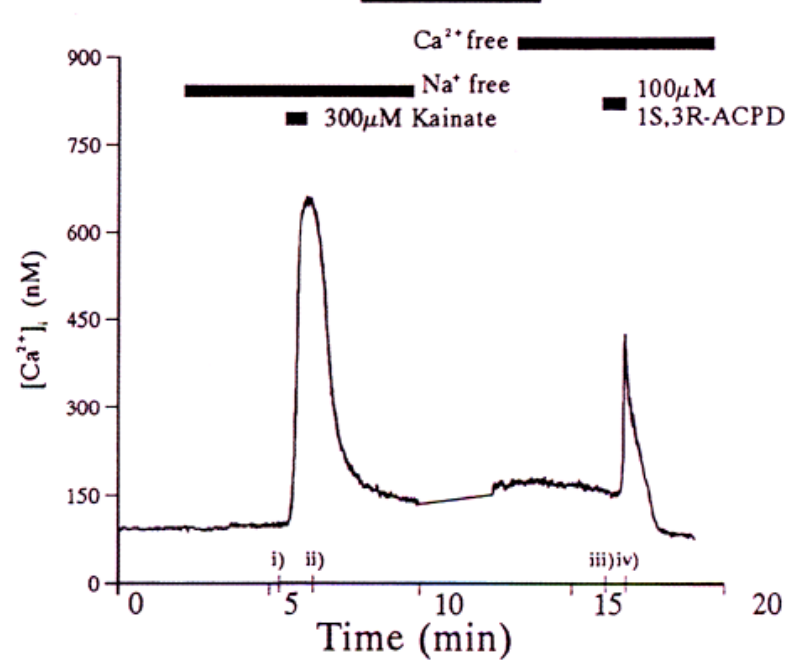



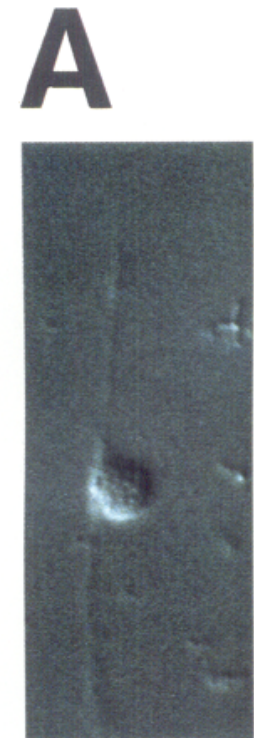

Nom

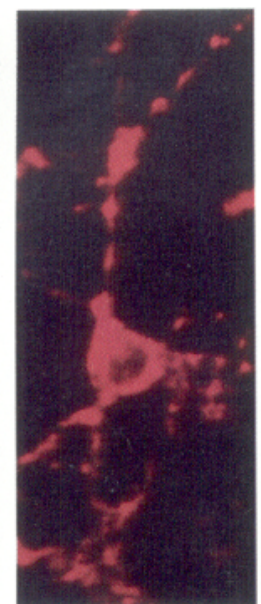

$\mathrm{A}_{2} \mathrm{~B}_{5}$

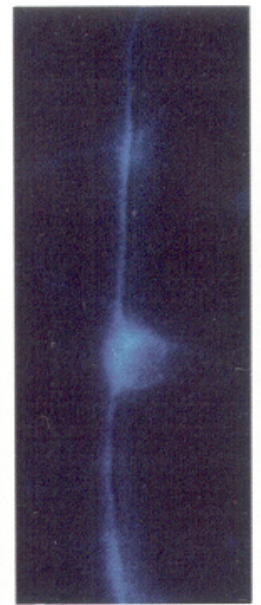

GFAP
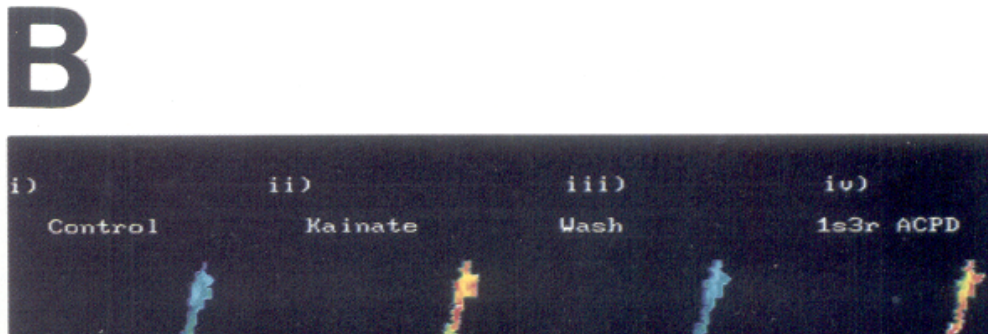

Wash $1 s 3 r$ ACPD
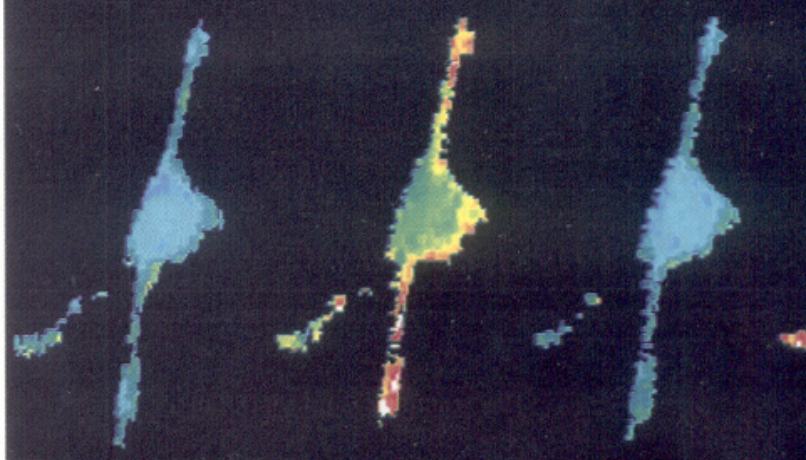

58 1989

[Ca] (nM)

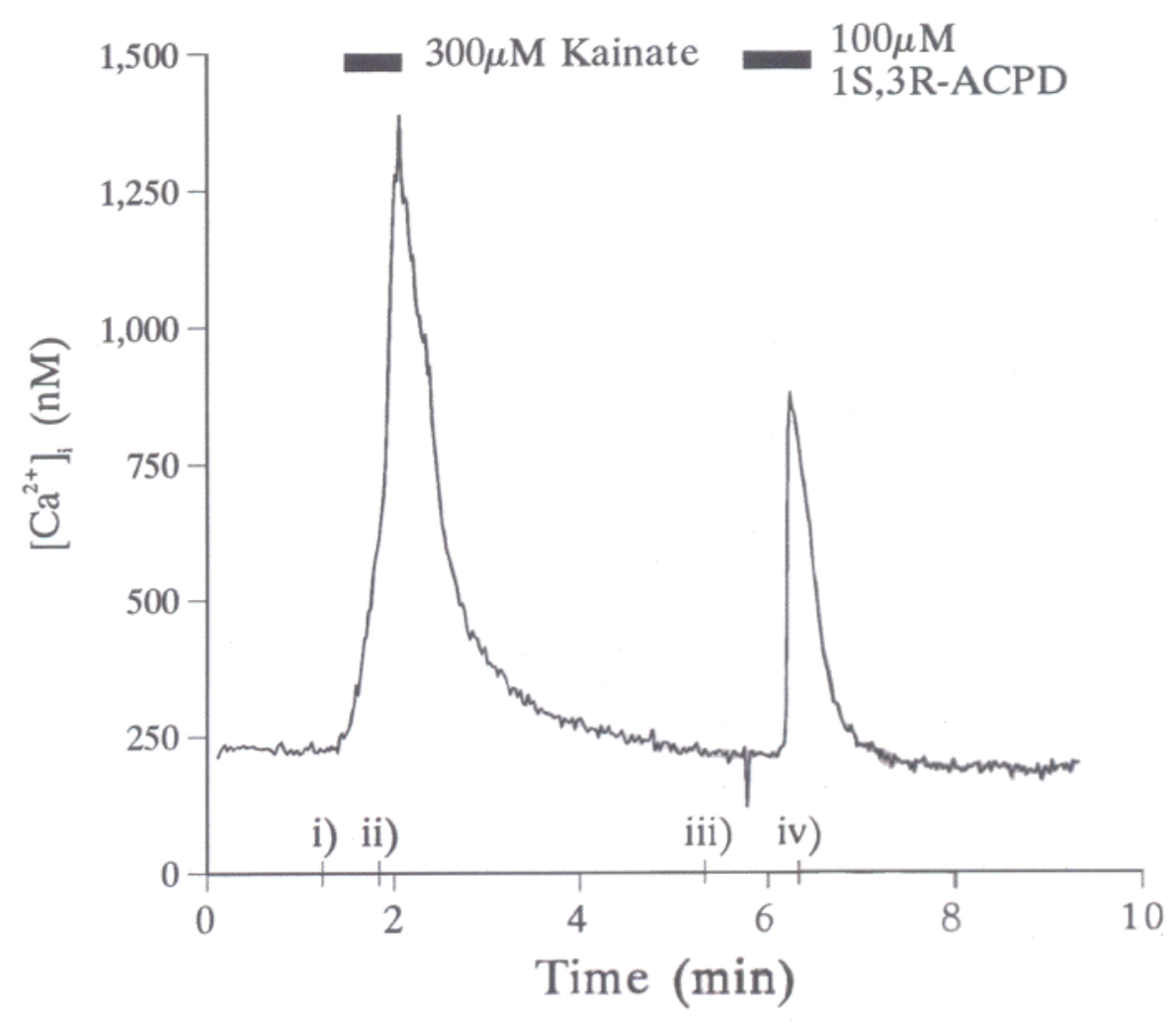

Figure 2. Example of a Ca ${ }^{2+}$ imaging-double labeling experiment. A gridded coverslip of cells was imaged and subsequently stained for $\mathbf{A}_{2} \mathbf{B}_{5}$ and GFAP. The three cells present are labeled 1,2 , and 3 . A. Staining. The first panel shows a photograph using Nomarski optics of the field of cells. The second panel shows positive staining for $\mathrm{A}_{2} \mathrm{~B}_{5}$. The third panel shows lack of staining for GFAP. Magnification, $327 \times . B, \mathrm{Ca}^{2+}$ imaging. This panel shows pseudocolor images of the same cells as stained in $A$. The images are labeled in sequence and the labels correspond with the tick marks on the $\mathrm{x}$-axis of the graphs in $C$. $C$, Time course of $\left[\mathrm{Ca}^{2+}\right]_{i}$ changes following application of $300 \mu \mathrm{M} \mathrm{KA}$ in Na+-free medium and $100 \mu \mathrm{M} 1 S, 3 R-$ ACPD in $\mathrm{Ca}^{2+}$-free medium for the cells identified by immunocytochemistry in $A . i$ ), ii), iii), and $i v$ ) indicate the points at which the corresponding pseudocolor images in $B$ were captured.

Figure 3. Example of $\mathrm{a} \mathrm{Ca}^{2+}$ imaging-double labeling experiment. A gridded coverslip of cells was imaged and subsequently stained for $\mathbf{A}_{2} \mathbf{B}_{5}$ and GFAP. A, Staining. The first panel shows a photograph using Nomarski optics of the cell studied. The second panel shows positive staining for $\mathrm{A}_{2} \mathrm{~B}_{5}$. The third panel shows positive staining for GFAP. Magnification, $720 \times, B, \mathrm{Ca}^{2+}$ imaging. This panel shows pseudocolor images of the same cell as stained in $A$. The images are labeled in sequence and the labels correspond with the tick marks on the $\mathrm{x}$-axis of the graph in $C$. $C$, Time course of $\left[\mathrm{Ca}^{2+}\right]$, changes following application of $300 \mu \mathrm{M} \mathrm{KA}$ and $100 \mu \mathrm{M} 1 S, 3 R$-ACPD in the cell identified by immunocytochemistry in $A$. $i$ ), ii), iii), and $i v)$ indicate the points at which the corresponding pseudocolor images in $B$ were captured. 


\section{Electrophysiology}

Whole-cell patch-clamp measurements were performed as previously described in full (Brorson et al., 1991). Cells were held at $-100 \mathrm{mV}$. $\mathrm{Na}^{+}$-containing solutions were as above, except with $3 \mathrm{~mm} \mathrm{KCl}$ and osmolarity adjusted to $305 \mathrm{mOsm}$ with $\mathrm{NaCl}$. $\mathrm{Na}^{+}$-free solutions contained (in mM) NMDG 145 or $133, \mathrm{CaCl}_{2} 2$ or 10 , HEPES 10 , glucose 10 , pII to 7.4 with $\mathrm{HCl}$, and osmolarity adjusted to $305 \mathrm{mOsm}$ with NMDG; $\mathrm{K}^{+}$and $\mathrm{Mg}^{2+}$ were omitted in order to isolate $\mathrm{Ca}^{2+}$ currents. Finally, high- $\mathrm{Ca}^{2+}$ solutions contained (in $\mathrm{mM}$ ) $\mathrm{CaCl}_{2} 110$, HEPES 10 glucose $10, \mathrm{pH} 7.4$. For measurements of ligand-gated currents, the intracellular solution contained (in mM) NMDG 145, BAPTA 10, pH to 7.1 with NMDG, and HF. For measurements of current-voltage ( $I /$ $V$ curves tetrodotoxin $(0.5 \mu \mathrm{M})$ and $\mathrm{Cd}^{2+}(100 \mu \mathrm{M})$ were added to the extracellular solution to block voltage-gated currents, and the intracellular solutions contained (in $\mathrm{mM}$ ) $\mathrm{CsF} 145$, BAPTA $10, \mathrm{pH}$ to 7.1 with NMDG, and HF. ATP was omitted to allow rundown of the voltagegated $\mathrm{Ca}^{2+}$ currents if present. Cells were accepted for study if a stable seal with a whole-cell resistance of at least $150 \mathrm{M} \Omega$ formed except in the case of the flat astrocytes, which consistently had low input resistance of 30-80 M $\Omega$. Patch pipettes of 1.5-4 M 2 were employed. Capacitive compensation and 30-60\% serics resistance corrections were employed in voltage clamp experiments. Agonists were applied by bath application; perfusion of the recording chamber was at a rate of $1-1.5 \mathrm{ml} / \mathrm{min}$ and full responses occurred within $30 \mathrm{sec}$ of onset. Figures have been corrected for a perfusion delay of approximately $20 \mathrm{sec}$. All experiments were performed at room temperature.

$I / V$ relationships were measured by $5 \mathrm{sec}$ ramp depolarizations from $-100 \mathrm{mV}$ to $+50 \mathrm{mV}$. The digital average of currents measured in control solution before and after agonist application was subtracted from an average of at least two $I / V$ curves measured during the plateau phase of KA application to obtain the $\mathrm{KA}$-induced $I / V$ curve; reversal potentials were determined from expanded plots of these $I / V$ curves.

\section{Polymerase chain reaction}

Cultured cortical astrocytes or neonatal rat whole cerebella were solubilized in $4 \mathrm{M}$ guanidine isothiocyanate (GITC) and total RNA isolated by the GITC/CsCl gradient ultracentrifugation method (Rappolee et al., 1989). cDNA was synthesized from the RNA using the GIBCO-Bethesda Research Labs Superscript Preamplification System kit, using reverse transcriptase $(200 \mathrm{U} / \mu \mathrm{l})$ and random hexamers $(50 \mathrm{ng} / \mu \mathrm{l})$. PCR was performed as follows. A $1-5 \mu \mathrm{l}$ sample of the reverse transcription product was included in a $50 \mu \mathrm{l} \mathrm{PCR}$ reaction mixture containing 200 $\mu \mathrm{M}$ dNTP, $2.5 \mathrm{~mm} \mathrm{MgCl}, 50 \mathrm{~mm} \mathrm{KCl}, 10 \mathrm{~mm}$ Tris- $\mathrm{HCl}$ (pH 8.3), 2.5 U AmpliTaq DNA polymerase (Cetus), and $1 \mu \mathrm{g} / \mathrm{ml}$ concentrations of primers. The mixture was overlaid with mineral oil and PCR carried out in a Perkin-Elmer DNA Thermal Cycler 480 according to the following protocol for amplification of subunits GluR2, -3 , and -5 : $94^{\circ} \mathrm{C}$ $\times 3 \mathrm{~min} ; 30$ cycles of $94^{\circ} \mathrm{C} \times 1 \mathrm{~min}, 60^{\circ} \mathrm{C} \times 1 \mathrm{~min}$, and $72^{\circ} \mathrm{C} \times 30$ sec; ending with $72^{\circ} \mathrm{C} \times 5$ min. For subunits GluR1, -4 , and -6 , the same protocol was followed except that an annealing temperature of $55^{\circ} \mathrm{C}$ was used. After amplification, a $5 \mu \mathrm{l}$ portion of the PCR mixture was added to $1 \mu \mathrm{l}$ of loading dye and electrophoresed in a $1.5 \%$ agarose gel in TAE buffer containing $0.5 \mu \mathrm{g} / \mathrm{ml}$ ethidium bromide. A 123 base pair DNA ladder (GIBCO) was used as a size marker. The gel was visualized and photographed under UV illumination.

Specific primers for each of the non-NMDA glutamate receptor subunits were designed from the published sequences and synthesized. The primers used were as follows-for GluR 1: upstream 5'-ATGCCGTACATCTTTGCC-3'; downstream 5'-AACAGGAAAACTTGGAGIA-3'; target length 345 base pairs; for GluR2: upstream 5'-GGTGTCTCTTCTAACAGC-3'; downstream 5'-AGAACAGCTTGCAGTGTTG-3'; target length 434; for GluR3: upstream 5'ATGGGGCAAAGCGTGCTCC-3'; downstream 5'-AAGGAGGTCAGGGTGTTCAT-3'; target length 329; for GluR4: upstream 5'-ATGAGGATTATTTGCAGG-3'; downstream 5'-ATGGCAAACACCCCTCTAG-3'; target length 281; for GluR5: upstream: 5'-ACCCTACGAGTGGTATAACC-3'; downstream 5'CCACAT(T/ C)TTCTC(A/G)TAGGTGGAG-3'; target length 389; for GluR6: upstream 5'-TTCAGTCGCTCCATTAAAGTCC-3'; downstream 5'TATTCTCTGTATTTAGTATCC-3'; target length 825 .

\section{Materials}

Fura-2 was purchased from Molecular Probes. All other chemicals and reagents were of the highest chemical grade and were purchased from
Sigma unless otherwise noted. Cyclothiazide was the generous gift of Lilly Pharmaceuticals, Indianapolis, IN.

\section{Results}

We had several goals in carrying out these experiments. The first was to ascertain whether activation of different types of glutamate receptors produced $\left[\mathrm{Ca}^{2+}\right]_{i}$ signals in cortical glia and to elucidate the mechanisms involved. In particular, considering recent work on the $\mathrm{Ca}^{2+}$ permeability of AMPA/KA receptors in Bergmann glia from the cerebellum (Burnashev et al., 1992a; Müller et al., 1992), we wished to ascertain whether this was also true for glia from other regions of the brain. Second, considering the heterogeneous nature of the cell types found in the cultures (see below), we also wished to ascertain whether there was any correlation between the types of $\left[\mathrm{Ca}^{2+}\right]_{i}$ responses observed and the different cell types present.

\section{Categorization of glial cells}

Cortical glial cells cultures contained a variety of morphological cell types that we further characterized by immunocytochemistry using antibodies against the glial markers complement receptor 3 (OX-42 antibody), glial fibrillary acidic protein (GFAP antibody), and ganglioside $G Q 1_{c}\left(A_{2} B_{5}\right.$ antibody). There was neither staining for neurofilament protein nor synaptophysin in the cultures, while parallel experiments on cultured cerebellar neurons (Brorson et al., 1991) exhibited positive staining.

Some cells in the cultures were flat and spread out on the coverslip in thin sheets (Fig. $1 A$ ). A second category of cells possessed a neuron-like morphology (Fig. $1 B$ ). These cells had round, phase-bright cell bodies with two or more long, thin processes. The remaining cells, which we termed "amorphous," had diverse morphologies, conforming to neither of the two other categories (Fig. 1C). Some of these had morphologics similar to cells described elsewhere (Fok-Seang and Miller, 1992) as "pancake glia."

Most of the flat cells stained brightly for GFAP (Fig. 1 $A$ ). The majority of the neuron-like cells stained brightly for $A_{2} B_{5}$ and about one-half also stained brightly for GFAP (Fig. $1 B$ ).

More than half of the amorphous cells stained with $\mathrm{OX}-42$. Ilowever, these cells did not stain in great numbers for GFAP or $\mathrm{A}_{2} \mathrm{~B}_{5}$. OX-42 stains complement receptor 3 , which has been reported to be an antigen found on microglia (Robinson et al., 1986; Ranson and Thomas, 1991). This pattern suggests that these cells are mainly microglia. In Figure $1 C$, two amorphous cells are shown that stained with OX-42 and not for GFAP. The relationship between the staining patterns observed and categories of glial cells previously defined in the literature will be further considered below (see Discussion).

\section{Calcium responses to glutamate receptor agonists}

We examined the effects of different types of glutamate receptor agonists on $\left[\mathrm{Ca}^{2+}\right]_{i}$ in cells whose staining pattern was subsequently determined. This was achieved through the use of gridded coverslips (see Materials and Methods). Typical examples of the use of this procedure are shown in Figures 2-4. In these experiments we used $1 S, 3 R$-ACPD in $\mathrm{Ca}^{2+}$-free solution to test for the presence of metabotropic glutamate receptor-mediated $\left[\mathrm{Ca}^{2+}\right]_{i}$ responses and $\mathrm{K} \Lambda$ to test for the presence of non-NMDA ionotropic glutamate receptors. None of the cells tested ever showed a response to NMDA even in $\mathrm{Mg}^{2+}$-free, glycine-supplemented solutions, which is consistent with previous obser- 
vations on the lack of these types of receptors on glia (Blankenfeld and Kettenmann, 1991).

The example in Figure 2 shows three cells that all stained positively for $\mathrm{A}_{2} \mathrm{~B}_{5}$ and wcre all ncgative for GFAP. These cells also exhibited a neuron-like morphology. The imaging portion of the figure shows that all of the cells responded positively to the addition of KA. On the other hand, only one cell responded positively to the addition of $1 S, 3 R$-ACPD. Figure 3 shows another cell also exhibiting a neuron-like morphology that stained positively for both $\mathrm{A}_{2} \mathrm{~B}_{5}$ and GFAP. This cell responded to both $\mathrm{KA}$ and $1 S, 3 R$-ACPD. Finally, the example illustrated in Figure 4 shows a flat cell that stained for GFAP but not for $A_{2} B_{5}$. This particular cell responded to $1 S, 3 R-\mathrm{ACPD}$, but not to $\mathrm{KA}$. It can be seen that the responses to KA always appeared as a simple rise in $\left[\mathrm{Ca}^{2+}\right]_{i}$ that declined following removal of the agonist. These responses were absolutely dependent on the presence of extracellular $\mathrm{Ca}^{2+}$ and no responses were observed when $\mathrm{Ca}^{2+}$ was removed. Thus, the responses to KA were at least initially dependent on $\mathrm{Ca}^{2+}$ influx (see also Fig. 8). On the other hand, responses to $\mathrm{KA}(300 \mu \mathrm{M})$ were not altered by the removal of extracellular $\mathrm{Na}^{+}$. The mean $\left[\mathrm{Ca}^{2+}\right]_{i}$ increase was $478 \pm 32 \mathrm{nM}$ in normal solution and $442 \pm 31 \mathrm{~nm}$ in $\mathrm{Na}^{+}$-free solution for 60 cells. (These data were taken from all cell types and not identified by staining, see also Fig. 6.) These results imply that $\mathrm{Na}^{+}$-dependent depolarization does not make an essential contribution to KA-induced $\mathrm{Ca}^{2+}$ influx in this instance (see also Discussion).

In contrast to the effects of $\mathrm{KA}$, responses to $1 S, 3 R$-ACPD exhibited a variety of forms. Sometimes the response showed just a single rise and fall in $\left[\mathrm{Ca}^{2+}\right]_{i}$ (e.g., Figs. 2, 3), but in other instances showed one or more oscillations following the initial response (e.g., Fig. 4; see also Glaum et al., 1990). All the effects of $1 S, 3 R$-ACPD were clearly due to $\mathrm{Ca}^{2+}$ mobilization from intracellular stores as these experiments were run in $\mathrm{Ca}^{2+}$-free solutions.

A summary of the distribution of the effects of different glutamate receptor agonists among cells with different staining profiles is shown in Figure 5. Only cells that could be unequivocally identified through their staining patterns were included in this analysis. It can be seen that the effects of $1 S, 3 R$-ACPD were quite evenly distributed, whereas there was a clear difference in the degree to which the different categories of cells responded to KA. Cclls that were positive for $A_{2} B_{5}$ responded more frequently than cells that were not. Cells that did not stain for either $A_{2} B_{5}$ or GFAP rarely responded to either agonist.

\section{Electrophysiological studies}

In order to obtain further information about the mechanism of action of glutamate in these cells, we also examined the effects of ionotropic glutamate receptor agonists on cortical glia using whole-cell patch-clamp techniques. Because of the difficulty in performing whole-cell patch-clamp studies and staining the same cells, glia were selected in these studies a priori using morphological criteria. The relationship between cells selected in this way and by the immunohistochemical procedures used in the $\left[\mathrm{Ca}^{2+}\right]_{i}$ measurements is discussed below (Discussion).

For the neuron-like cells, application of $\mathrm{KA}(300 \mu \mathrm{M})$ induced substantial inward currents in $\mathrm{Na}^{+}$-containing solutions but only very small currents in $\mathrm{Na}^{+}$-free solutions (Figs. 6, 7). The mean response to $\mathrm{KA}(300 \mu \mathrm{M})$ in $\mathrm{Na}^{+}$-containing solutions, measured with monovalent cation-free intracellular solutions, was an inward current of $409 \pm 210 \mathrm{pA}$, while in the same cells it was only $13 \pm 5 \mathrm{pA}$ in $\mathrm{Na}^{+}$-free solutions $(n=10)$. Responses were similar whether or not TTX $(0.5 \mu \mathrm{M})$ and $\mathrm{Cd}^{2+}(100 \mu \mathrm{M})$ were included in order to block any voltage-gated $\mathrm{Na}^{+}$and $\mathrm{Ca}^{2+}$ channcls.

To explore further the relationship between the substantial $\mathrm{KA}$-induced $\left[\mathrm{Ca}^{2+}\right]_{i}$ increases described above and the lack of large KA-induced $\mathrm{Ca}^{2+}$ currents in the neuron-like cells, four cells were studied with fura-2 microfluorimetry followed by patch-clamp measurements of KA-activated currents in the same cells. In a typical example illustrated in Figure $6 \mathrm{~A}$, kainate produced a large rise in $\left[\mathrm{Ca}^{2+}\right]_{i}$ that was almost as large in $\mathrm{Na}^{+}$. free solution as in $\mathrm{Na}^{+}$-containing solution. It should be noted that voltage-sensitive $\mathrm{Ca}^{2+}$ current was absent from this cell. Interestingly, although KA produced a large current in normal solution, it was very small in $\mathrm{Na}^{+}$-free solution. Nevertheless, this small ligand-gated $\mathrm{Ca}^{2}$ i current was apparently sufficient to produce the large rise in $\left[\mathrm{Ca}^{2+}\right]_{i}$.

The current-voltage relationships of the kainate-induced currents were studied using $\mathrm{Cs}^{+}$-containing intracellular solutions. The characteristics of the KA currents in $\mathrm{Na}^{+}$-containing solutions were similar to those reported to result from AMPA/ $\mathrm{KA}$ receptors that are impermeable to divalent cations (Hollmann et al., 1991). Thus, the current-voltage curves were outwardly rectifying without a measurable shift with changes in $\left[\mathrm{Ca}^{2+}\right]_{0}$ (Fig. $7 A$ ). In $\mathrm{Na}^{+}$-free solutions, very small $\mathrm{KA}$-induced inward currents were observed, but the outward currents carried by $\mathrm{Cs}^{\prime}$ emux via monovalent cation-permeable receptors dominated the current-voltage relationship (Fig. 7B). The lack of substantial inward currents when $\mathrm{Cs}^{+}$was included in the intracellular solution often precluded accurate measurements of the reversal potential (Fig. $7 B, C$ ). However, cyclothiazide (10 $\mu \mathrm{M})$ substantially increased the size of the KA-induced currents both in $\mathrm{Na}^{+}$-containing and $\mathrm{Na}^{+}$-free solutions without significantly shifting the reversal potential (Fig. $7 D$ ). In the presence of cyclothiazide, the reversal potential of the KA-induced currents in $\mathrm{Na}^{+}$-free, $2 \mathrm{mM} \mathrm{Ca}^{2+}$-containing solutions was found to vary widely, from -94 to $-61 \mathrm{mV}$, with an average of -81 $\pm 2 \mathrm{mV}(n=14)$. In $10 \mathrm{mM} \mathrm{Ca}^{2+}$, the reversal potential shifted to $-67 \pm-5 \mathrm{mV}(n=6)$. Using the constant-field equation to approximate the relative permeabilities (Iino et al., 1990), the mean reversal potential in $2 \mathrm{mM} \mathrm{Ca}^{2+}$ predicts a net $\mathrm{Ca}^{2+}$ to $\mathrm{Cs}^{+}$permeability ratio of 0.82 , and that in $10 \mathrm{mM} \mathrm{Ca}^{2+}$ predicts a ratio of 0.29 for the composite of KA receptors expressed on these cells. These calculations must be viewed with caution, however, given the possible limitations of space clamping of these geometrically complex glia. Nevertheless, the qualitative effect of increasing the $\left[\mathrm{Ca}^{2+}\right]$, from 2 to $10 \mathrm{~mm}$ was clear, shifting the reversal potential in the depolarizing direction in each case, by an average of $+10 \pm-2 \mathrm{mV}(n=6)$.

For glia of other morphology, membrane currents were less prominent. Flat cells responded to $300 \mu \mathrm{M} \mathrm{KA}$ with inward currents in $\mathrm{Na}^{+}$containing solution. The overall mean current was $54 \pm 21 \mathrm{pA}$ ( $n=6 ; 4 / 6$ cells responding). In $\mathrm{Na}^{+}$-free solutions no inward currents were detectable. Cells in the amorphous category exhibited no voltage-gated $\mathrm{Na}^{+}$or $\mathrm{Ca}^{2+}$ currents or currents in response to $300 \mu \mathrm{M} \mathrm{KA}(n=4)$.

\section{Cobalt permeation of receptors}

The $\left[\mathrm{Ca}^{2+}\right]_{i}$ microfluorimetric data and the clectrophysiological measurements clearly indicated that non-NMDA agonists could induce $\mathrm{Ca}^{2+}$ entry in cortical glial cells. The hypothesis that $\mathrm{Ca}^{2+}$ could directly enter glial cells through glutamate receptor- 

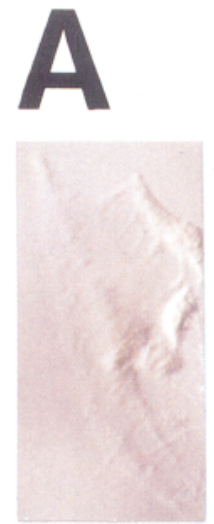

Nom

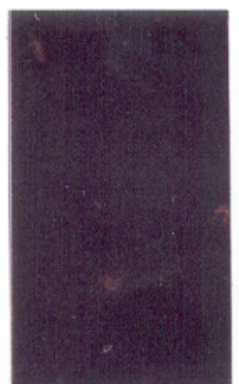

$\mathrm{A}_{2} \mathrm{~B}_{5}$

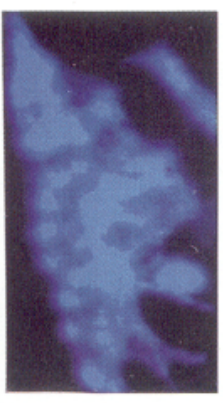

GFAP

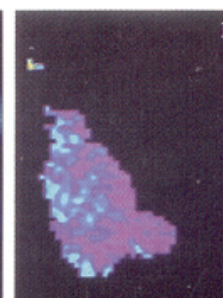

i)

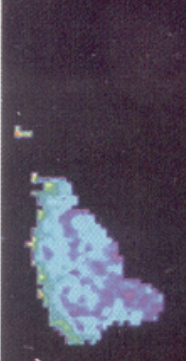

u)
Ka inate
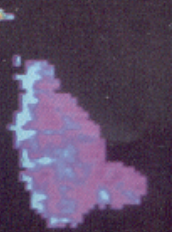

i i)

25

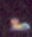

th.

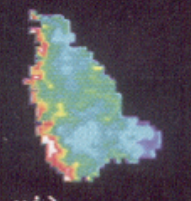

ui)

L $\quad$ AC

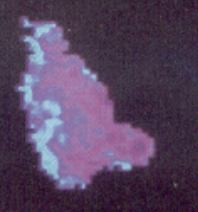

i i i)
ACPD
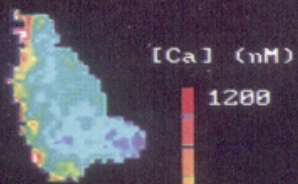

iv)

1280

59
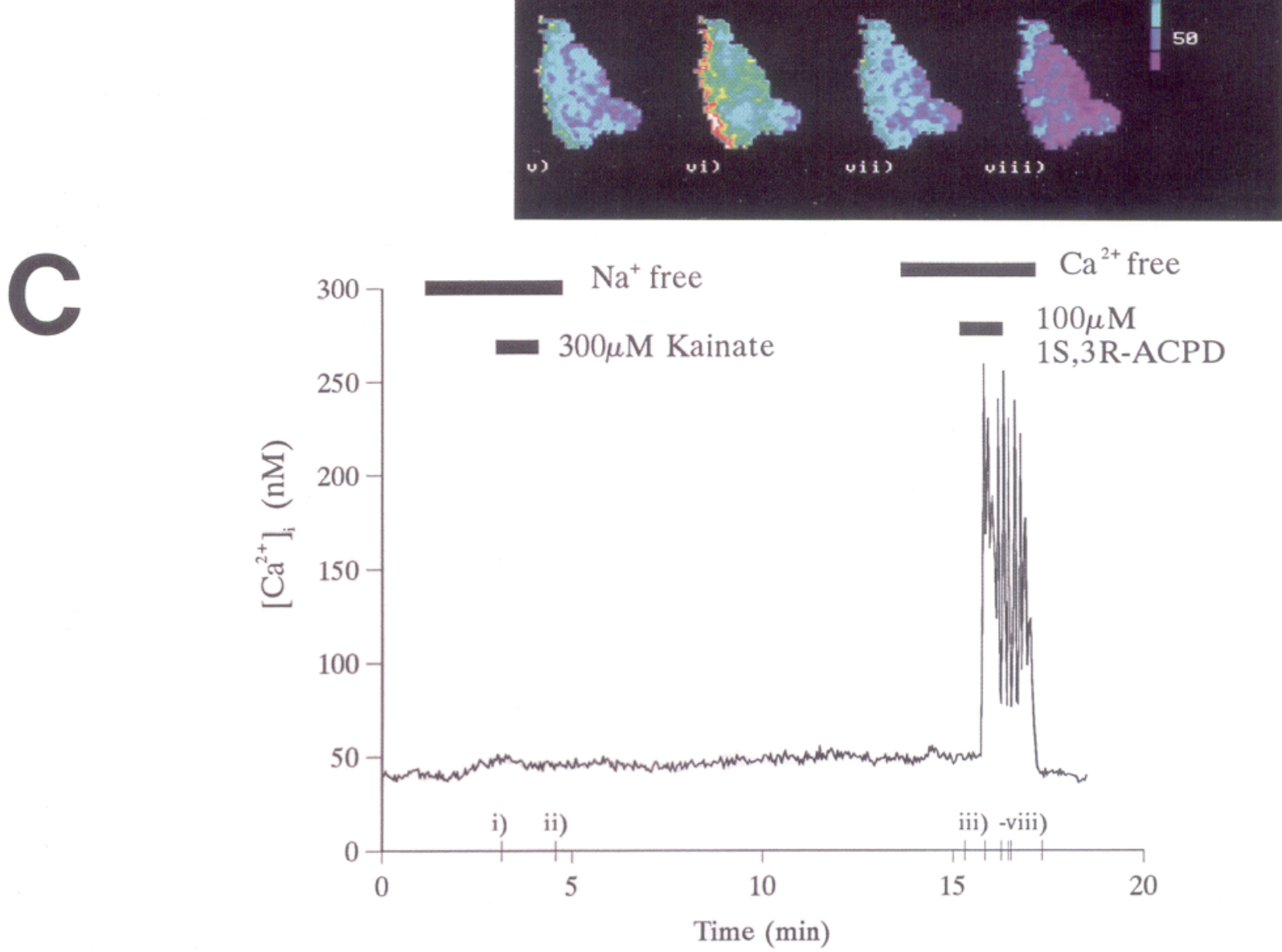

Figure 4. Example of a $\mathrm{Ca}^{2+}$ imaging-double labeling experiment. A gridded coverslip of cells was imaged and subsequently stained for $\mathrm{A}_{2} \mathrm{~B}_{5}$ and GFAP. A, Staining. The first panel shows a photograph using Nomarski optics of the cell studied. The second panel shows negative staining for $\mathrm{A}_{2} \mathrm{~B}_{5}$. The third panel shows positive staining for GFAP. Magnification, $310 \times . \mathrm{B}, \mathrm{Ca}^{2+}$ imaging. This panel shows pseudocolor images of the same cell as stained in $A$. The images are labeled in sequence and the labels correspond with the tick marks on the $\mathrm{x}$-axis of the graphs in $C$. $C$, Time course of $\left[\mathrm{Ca}^{2+}\right]_{i}$ changes following application of $300 \mu \mathrm{M} \mathrm{KA}$ in $\mathrm{Na}^{+}$-free medium and $100 \mu \mathrm{M} 1 S, 3 R$-ACPD in Ca ${ }^{2+}$-free medium in the cell identified by immunocytochemistry in $A$. $i$ )-viii) indicate the points at which the corresponding pseudocolor images in $B$ were captured. This graph shows an oscillatory response to $100 \mu \mathrm{M} 1 S, 3 R$-ACPD in $\mathrm{Ca}^{2+}$-free medium.

linked ion channels was further tested by examining agonistinduced $\mathrm{Co}^{2+}$ fluxes in these cells. $\mathrm{Ca}^{2+}$-permeable AMPA/KA receptors are nonselective for divalent cations, and are permeable to a number of cations including $\mathrm{Co}^{2+}$ (Iino et al., 1990; Pruss et al., 1991). However, $\mathrm{Co}^{2+}$ is not thought to permeate voltage-sensitive $\mathrm{Ca}^{2+}$ channels or NMDA channels (Mayer and
Westbrook, 1987). Indeed, $\mathrm{Co}^{2+}$ is a very effective blocker of voltage-dependent $\mathrm{Ca}^{2+}$ channels (Hagiwara and Byerly, 1981). $\mathrm{Co}^{2+}$ entry into glial cells could easily be monitored in our experiments as it effectively quenches fura- 2 fluorescence. In neuron-like cells, which responded to kainate in the absence of external $\mathrm{Na}^{+}$, depolarization of the cells with $50 \mathrm{~mm} \mathrm{~K}{ }^{+}$pro- 


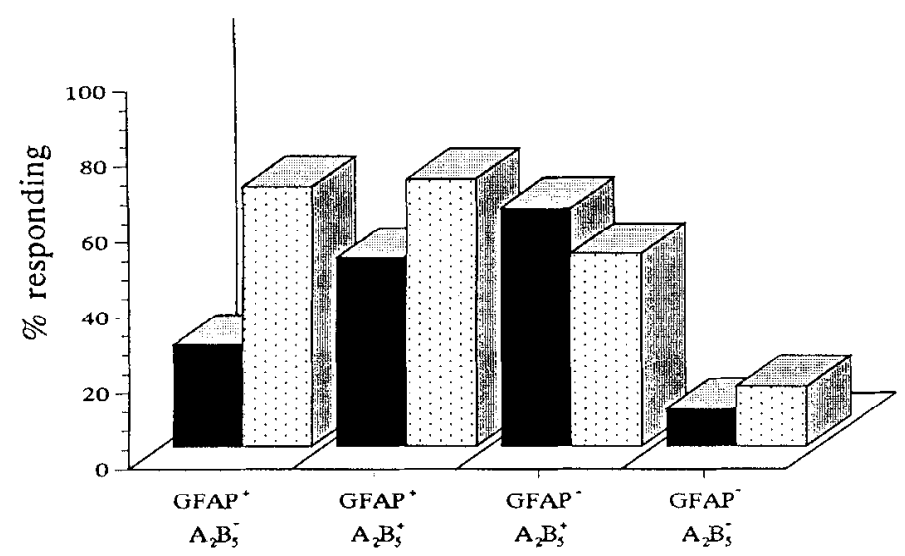

Figure 5. Summary of distribution of cells responding to KA and IS $3 R$-ACPD. This graph represents the percentage of cells responding to $300 \mu \mathrm{M} \mathrm{KA}$ in $\mathrm{Na}^{+}$-free medium and $100 \mu \mathrm{M} 1 S, 3 R$-ACPD in $\mathrm{Ca}^{2+}$ free medium for each of the staining patterns observed (GFAP ${ }^{+} \mathrm{A}_{2} \mathrm{~B}_{5}{ }^{+}$, GFAP ${ }^{+} \mathrm{A}_{2} \mathrm{~B}_{5}{ }^{-}$, GFAP- $\mathrm{A}_{2} \mathbf{B}_{5}{ }^{+}$, GFAP ${ }^{-} \mathbf{A}_{2} \mathbf{B}_{5}{ }^{-}$). Cells were considered to respond if they had a rise of greater than $50 \mathrm{~nm}$ after application of the drug, which returned to baseline following removal of the drug. This graph represents 224 cells ( $n=14$ coverslips). There were $48 \mathrm{GFAP}^{+}$ $\mathrm{A}_{2} \mathrm{~B}_{5}{ }^{+}$cells, $71 \mathrm{GFAP}+\mathrm{A}_{2} \mathrm{~B}_{5}{ }^{-}$cells, 54 GFAP $\mathrm{A}_{2} \mathrm{~B}_{5}{ }^{+}$cells, and 51 GFAP ${ }^{-} \mathrm{A}_{2} \mathrm{~B}_{5}{ }^{-}$cells. The black bars represent responses to $\mathrm{KA}$ and the dotted bars represent responses to $1 S, 3 R$-ACPD.

duced no change in the intensity of the fura-2 signal when $\mathrm{Co}^{2+}$ was substituted for $\mathrm{Ca}^{2+}(n=3$ of 3 ; Fig. 8). In contrast, $\mathrm{KA}$ stimulation in the presence of $\mathrm{CO}^{2+}$ produced a rapid quenching of the fura-2 signal ( $n=6$ of 6 ). This indicates that KA can activate a pathway in these cells that is permeable to divalent cations including $\mathrm{Co}^{2+}$.

\section{$\mathrm{Ca}^{2+}$ stores}

One possible explanation for the results obtained with $\mathrm{KA}$ is that a small amount of $\mathrm{Ca}^{2+}$ enters the cells through the $\mathrm{KA}$ receptor and this triggers a much larger release of $\mathrm{Ca}^{2+}$ from intracellular stores through $\mathrm{Ca}^{2+}$-induced $\mathrm{Ca}^{2+}$ release (Miller, $1991 \mathrm{c})$. However, the experiments illustrated in Figure 9 suggest that this is not the case. It can be seen that following treatment of cells with thapsigargin to deplete intracellular $\mathrm{Ca}^{2+}$ stores (Inesi and Sagara, 1992), KA still produced a substantial increase in $\left[\mathrm{Ca}^{2+}\right]_{i}$, although $1 S, 3 R$-ACPD no longer did so. The response to a second application of $\mathrm{KA}$ following thapsigargin treatment was $64 \pm 14 \%$ of the first response ( $n=14$ cells of various morphologies). The response to $1 S, 3 R$-ACPD was 12 $\pm 3 \%$ of the first response following thapsigargin treatment ( $n$ $=24$ cells of various morphologies). Thus, although a small contribution from intracellular stores cannot be ruled out, it appears that most of the $\mathrm{KA}$-induced $\left[\mathrm{Ca}^{2+}\right]_{i}$ increase is due solely to $\mathrm{Ca}^{2+}$ influx.

\section{Glial glutamate receptor subunit expression}

In order to account for the observed KA responses in terms of the expression of non-NMDA glutamate receptor subunits, we employed PCR amplification of GluR 1-6, using the published sequences to derive pairs of specific primers for each subunit. PCR was applied to cDNA synthesized from cultured cortical glia after $17 \mathrm{~d}$ in vitro (Fig. 10). PCR produced bands for GluR1, GluR2, GluR3, GluR4, and GluR6. However, no evidence for GluR5 expression was found. Each of these bands was of the appropriate size predicted from the sequence data. The positive controls for each subunit, using cDNA from adult rat cerebrum or adult rat whole cerebellum, showed appropriate positive bands for each subunit. Unlike the reported situation in Bergmann glia, in which only GluR4 was found (Burnashev et al., 1992a), these results suggest the expression of multiple glutamate receptor subunits including GluR $1-4$ and GluR6 subunits among the glial types present in these cultures. PCR is not quantitative under our conditions, and the relative levels of expression of the various receptor subunits have not been determined.

\section{Discussion}

The experiments reported here show that activation of both non-NMDA ionotropic and metabotropic glutamate receptors can cause increases in $\left[\mathrm{Ca}^{2+}\right]_{i}$ in cultured cortical glia - an observation that is consistent with several previous reports in the literature (Enkvist et al., 1989; Milani et al., 1989; Ahmed et al., 1990; Cornell-Bell et al., 1990a; Glaum et al., 1990; Jensen and Chiu, 1990, 1991). There were several types of cells observed in the cultures that could potentially have been classified according to several criteria. We chose to use the staining pattern observed with antisera specific for certain key glial antigens as a means of categorizing the cells. It is interesting to ask how the cell types differentiated immunocytochemically in our studies correspond to other categories previously defined in the literature. Although we cannot make such an assignation exactly, there are clearly some similarities. For example, the cells that stain for $A_{2} B_{5}$ are presumably of the $O 2-A$ lineage and probably include $\mathrm{O} 2-\mathrm{A}$ progenitor cells and type 2 astrocytes (Raff et al., $1983 \mathrm{a}, \mathrm{b})$. This would certainly be consistent with the large numbers of cells in this category possessing a neuron-like morphol-
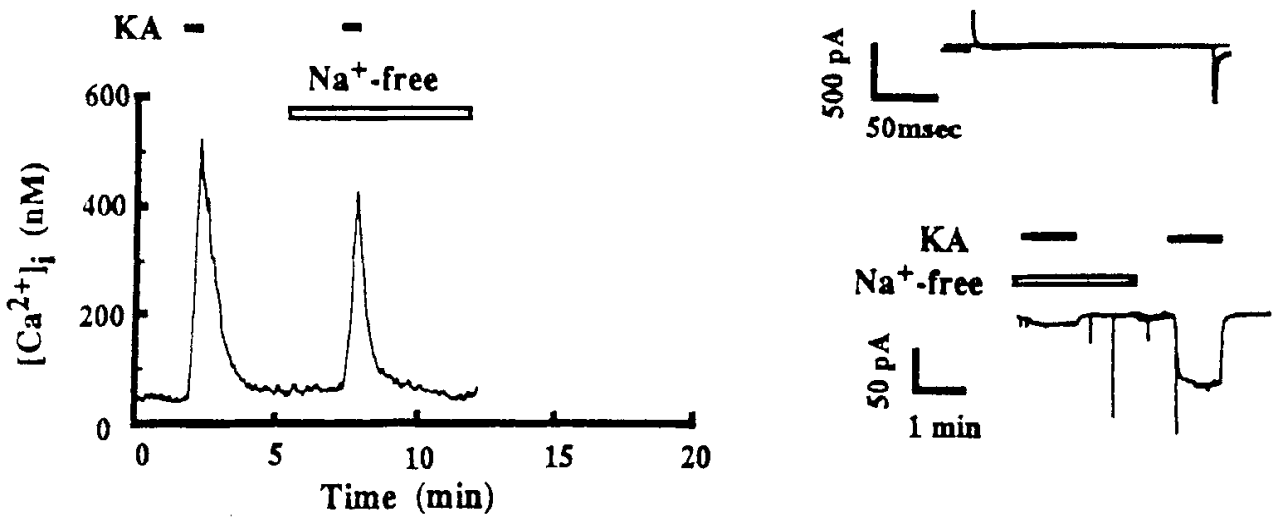

Figure 6. KA-induced $\mathrm{Ca}^{2+}$ influx and whole-cell currents: representative traces from a single glial cell show substantial $\mathrm{KA}$-induced $\mathrm{Ca}^{2+}$ influx in $\mathrm{Na}^{+}$containing and $\mathrm{Na}$-free solutions (left) and subsequent measurement of wholecell currents (right). This cell had no measurable voltage-gated $\mathrm{Ca}^{2+}$ currents, minimal KA-induced current in $\mathrm{Na}^{+}$-free solution, and a larger KA-induced $\mathrm{Na}^{+}$current. This is a representative example of four similar experiments. (Intracellular solution, NMDG fluoride, $10 \mathrm{~mm}$ BAPTA.) 

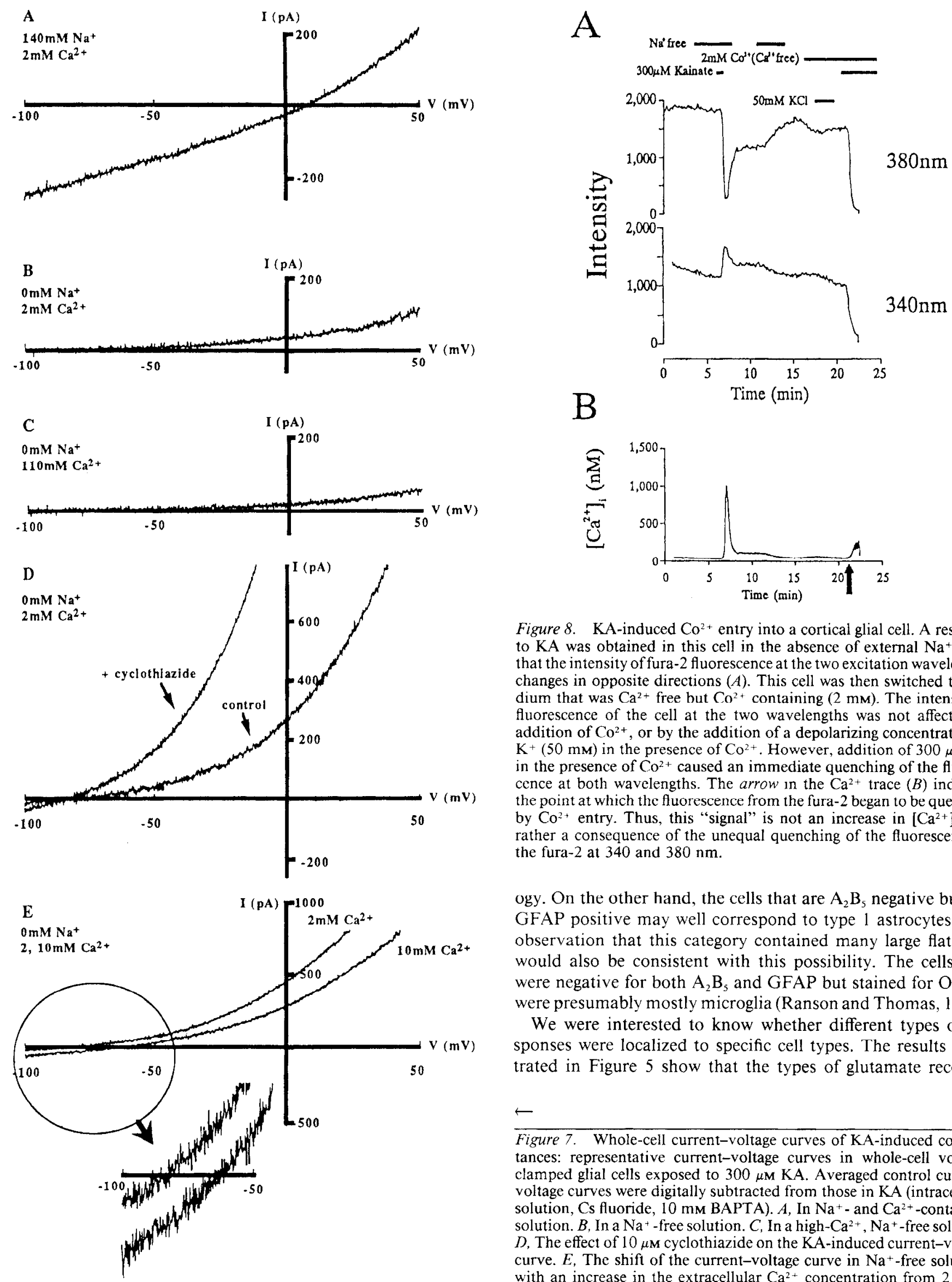

Figure 8. KA-induced $\mathrm{Co}^{2+}$ entry into a cortical glial cell. A response to $\mathrm{KA}$ was obtained in this cell in the absence of external $\mathrm{Na}^{+}$; note that the intensity of fura-2 fluorescence at the two excitation wavelengths changes in opposite directions $(A)$. This cell was then switched to medium that was $\mathrm{Ca}^{2+}$ free hut $\mathrm{Co}^{2+}$ containing $(2 \mathrm{mM})$. The intensity of fluorescence of the cell at the two wavelengths was not affected by addition of $\mathrm{Co}^{2+}$, or by the addition of a depolarizing concentration of $\mathrm{K}^{+}(50 \mathrm{~mm})$ in the presence of $\mathrm{Co}^{2+}$. However, addition of $300 \mu \mathrm{M} \mathrm{KA}$ in the presence of $\mathrm{Co}^{2+}$ caused an immediate quenching of the fluorescence at both wavelengths. The arrow in the $\mathrm{Ca}^{2+}$ trace $(B)$ indicates the point at which the fluorescence from the furd -2 began to be quenched by $\mathrm{Co}^{2+}$ entry. Thus, this "signal" is not an increase in $\left[\mathrm{Ca}^{2+}\right]_{l}$, but rather a consequence of the unequal quenching of the fluorescence of the fura- 2 at 340 and $380 \mathrm{~nm}$.

ogy. On the other hand, the cells that are $\mathrm{A}_{2} \mathrm{~B}_{5}$ negative but are GFAP positive may well correspond to type 1 astrocytes. The observation that this category contained many large flat cells would also be consistent with this possibility. The cells that were negative for both $\mathrm{A}_{2} \mathrm{~B}_{5}$ and GFAP but stained for OX-42 were presumably mostly microglia (Ranson and Thomas, 1991).

We were interested to know whether different types of responses were localized to specific cell types. 'The results illustrated in Figure 5 show that the types of glutamate receptor

$\leftarrow$

Figure 7. Whole-cell current-voltage curves of KA-induced conductances: representative current-voltage curves in whole-cell voltageclamped glial cells exposed to $300 \mu \mathrm{M} \mathrm{KA}$. Averaged control currentvoltage curves were digitally subtracted from those in KA (intracellular solution, Cs fluoride, $10 \mathrm{~mm}$ BAPTA). $A$, In $\mathrm{Na}^{+}$- and $\mathrm{Ca}^{2+}$-containing solution. $B$, In a Na ${ }^{+}$-free solution. $C$, In a high-Ca ${ }^{2+}, \mathrm{Na}^{+}$-free solution. $D$. The effect of $10 \mu \mathrm{M}$ cyclothiazide on the KA-induced current-voltage curve. $E$, The shift of the current-voltage curve in $\mathrm{Na}^{+}$-free solutions with an increase in the extracellular $\mathrm{Ca}^{2+}$ concentration from 2 to 10 mм (10 $\mu \mathrm{M}$ cyclothiazide present). 


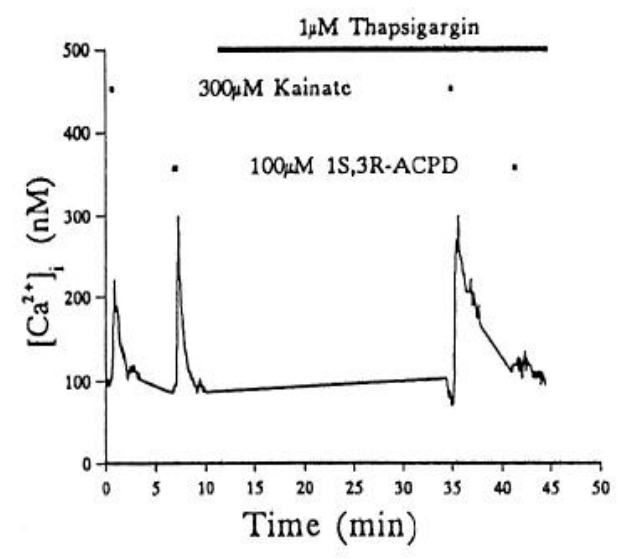

Figure 9. A typical example of the effect of thapsigargin on the responses of a cortical glial cell. First the cell was exposed to $300 \mu \mathrm{M} \mathrm{KA}$, as indicated by the bar above the tract. The KA was washed out and $100 \mu \mathrm{M} 1 S, 3 R$-ACPD was added as indicated. After the $1 S, 3 R$-ACPD was washed out, $1 \mu \mathrm{M}$ thapsigargin was added as indicated and remained in the perfusate for the remainder of the experiment. At the indicated times $300 \mu \mathrm{M} \mathrm{KA}$ and $100 \mu \mathrm{M} 1 S, 3 R$-ACPD were added again. The effect of KA is only slightly changed, whereas the effect of $1 S, 3 R-\mathrm{ACPD}$ is completely blocked, indicating that the intracellular $\mathrm{Ca}^{2+}$ stores are emptied by thapsigargin treatment.

responses we observed were not completely localized to a single category of cells. This was particularly true of the responses to metabotropic receptor activation, which were found to be quite evenly distributed. This seems to be consistent with previous reports describing cells with different morphologies responding to metabotropic glutamate receptor agonists (Ahmed et al., 1990; Barry et al., 1991). As we usually utilized $1 S, 3 R$-ACPD in $\mathrm{Ca}^{2+}$ free solutions, it is clear that the responses we observed were due to the mobilization of intracellular $\mathrm{Ca}^{2+}$, presumably resulting from the synthesis of 1,4,5-inositol trisphosphate $\left(\mathrm{IP}_{3}\right)$ (Yuzaki and Mikoshiba, 1992; Miller et al., 1993). This would be consistent with the presence of either mGluR 1 or -5 in these cells (Abe et al., 1992; Grocs et al., 1993; Schoepp and Conn, 1993). However, to date, only mGluR3 (and sometimes in mGluR4) has been shown to be expressed in glia from different parts of the brain, and this is a receptor that is not normally thought to be linked to $\mathrm{IP}_{3}$ synthesis (Burnashev et al., 1992b; Shigemoto, 1993; Tanabe et al., 1993). Thus, it is possible that a further as yet unidentified $\mathrm{mGluR}$ is responsible for the effects observed. In addition to mGluR3, it is clear that there are several types of mGluRs that are not coupled to activation of phospholipase $\mathrm{C}$ and would not necessarily produce changes in $\left[\mathrm{Ca}^{2+}\right]_{i}$ (Schoepp and Conn, 1993). Our studies do not rule out the possible presence of metabotropic glutamate receptors coupled to other effectors (see, e.g., Schwartz, 1993).

In contrast to the situation with the mGluRs, it is clear that the majority of the ionotropic glutamate responses were localized to cells in the O-2A lineage cells, as might be expected from previous reports (Wyllie et al., 1991; Stephens et al., 1993). The mechanism by which agonists at non-NMDA receptors raise $\left[\mathrm{Ca}^{2+}\right]_{i}$ in these cells is not completely clear. Depolarization of glia by agonists at non-NMDA receptors has been previously demonstrated in a number of studies (Bowman and Kimelberg, 1984; Sontheimer et al., 1988; Backus et al., 1989; Enkvist et al., 1989; Usowicz et al., 1989; Wyllie et al., 1991; Berger et al., 1992; Clark and Mobbs, 1992), as have increases in $\left[\mathrm{Ca}^{2+}\right]$ in response to the same agonists (Enkvist et al., 1989; Cornell-

\section{Cultured Cortical Glia}
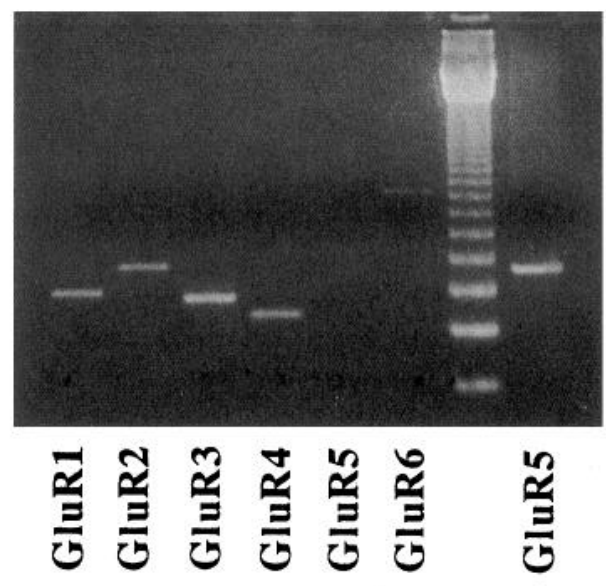

Figure 10. PCR for GluR1-6 receptor subunits. PCR was performed as described on cDNA synthesized from cultured cortical glia, $17 \mathrm{~d}$ in culture, using specific primers for GluR $1-6$. The PCR products were visualized by ethidium bromide staining of a $1.5 \%$ agarose gel. Lanes contain PCR products produced with primers for the various glutamate receptor subunits as indicated. Bands of appropriate length for subunits GluR 1-, $-2,-3,-4$, and -6 were produced using cDNA from the cultured glia, whereas GluR5 primers failed to amplify a band from the cultured glial cDNA. A 123 base pair DNA ladder (lane 7) is included as a size marker. The activity of the GluR5 primers was confirmed in parallel positive reactions with cDNA synthesized from dorsal root ganglion neurons (DRGs) dissociated from 5-d-old rat pups (lane 8 ), as well as on whole cerebellar cDNA (not shown). In addition, the glial cDNA used for the GluR5 PCR reaction was tested with a parallel positive control reaction with the GluR2 primers. For each of the primers, parallel control reactions with omission of the cDNA were negative (not shown).

Bell et al., 1990a; Glaum et al., 1990; Jensen and Chiu, 1990, 1991). Some of these increases could be the result of direct $\mathrm{Ca}^{2+}$ permeation through AMPA/KA receptors. In the case of the Bergmann glia in the cerebellum, it has been shown that $\mathrm{Ca}^{2+}$ does directly enter through $\mathrm{Ca}^{2+}$-permeable AMPA/KA receptors (Burnashev et al., 1992a; Muller et al., 1992). AMPA/KA receptors in these cells exhibit all the characteristics of the $\mathrm{Ca}^{2+}$. permeable receptors artificially constructed in oocytes, including large inwardly rectifying currents in $\mathrm{Na}^{+}$-free solutions with reversal potentials that shift with $\left[\mathrm{Ca}^{2+}\right]_{o}$. Bergmann glia are devoid of the GluR2 subunit, the edited version of which effectively suppresses the $\mathrm{Ca}^{2+}$ permeability of AMPA/KA receptors (Burnashev et al., 1992b). Thus, their expression of a pure population of $\mathrm{Ca}^{2+}$-permeable AMPA/KA receptors can easily be understood on a molecular basis.

The situation in cortical cultures appears to be quite different from that in the Bergmann glia. The KA-responsive cells, presumably mostly O-2A progenitor cells and type 2 astrocytes (see above), do exhibit large increases in $\left[\mathrm{Ca}^{2+}\right]_{i}$ in response to nonNMDA agonists even in the absence of extracellular $\mathrm{Na}^{+}$. However, the same cells only show very small KA-induced currents in the absence of extracellular $\mathrm{Na}^{+}$(see also Stephens et al., 1993). Under these conditions, the KA-induced currents were dominated by the outwardly rectifying monovalent conductance. Nevertheless, when the magnitude of these currents was boosted by the addition of cyclothiazide, a rightward shift of the reversal potential was seen with increasing $\left[\mathrm{Ca}^{2+}\right]_{o}$, suggesting an inward current component carried by $\mathrm{Ca}^{2+}$ ions. Fi- 
nally, the cultures contained strong expression of GluR2 as well as expression of subunits GluR $1,-3,-4$, and -6 . Presumably these subunits are derived from the population of cells that includes those showing electrophysiological responses to KA. The pattern of subunit expression is consistent with the electrophysiological findings, since GluR2 (edited) combines with other subunits (GluR1, -3 , and -4) to produce AMPA/KA receptors with low divalent cation permeability (Hollmann et al., 1991). Our results can be compared to those obtained by Wyllie and Cull-Candy (1991), who observed a low $\mathrm{Ca}^{2+}$ permeability of KA-activated channels in "type 2 astrocytes." However, they did not simultaneously measure changes in $\left[\mathrm{Ca}^{2+}\right]_{i}$ induced by KA.

Given that the majority of the KA-induced current is carried by monovalent cations in these cells, how then can we understand the finding that these cells demonstrate large increases in $\left[\mathrm{Ca}^{2+}\right]_{i}$ in $\mathrm{Na}^{+}$-free solutions (see also Enkvist et al., 1989; Jensen and Chiu, 1990, 1991)? It is unlikely that the influx occurs through voltage-sensitive $\mathrm{Ca}^{2+}$ channels in these cells for several reasons. First, although we have not spccifically studicd this question, voltage-sensitive $\mathrm{Ca}^{2+}$ currents were often absent from cells that showed large responses to KA (e.g., Fig. 6). Moreover, although such currents are sometimes observed in glia (e.g., Blankenfeld et al., 1992; J. A. Holzwarth, S. J. Gibbons, J. R. Brorson, L. H. Philipson, and R. J. Miller, unpublished observations), they are small in our experience. It should also be noted that we routinely observed KA-induced $\mathrm{Ca}^{2}{ }^{1}$ currents in our electrophysiological studies in the presence of enough $\mathrm{Cd}^{2+}$ to block voltage-dependent $\mathrm{Ca}^{2+}$ channels. Furthermore, in the $\mathrm{Ca}^{2+}$ imaging studies, KA provoked large increases in $\left[\mathrm{Ca}^{2+}\right]_{i}$ even in the absence of extracellular $\mathrm{Na}^{+}$, which would limit the ability of KA to depolarize the cells.

The best explanation of the present results is probably that the cells contain a mixed population of receptors. The expression of a mosaic of $\mathrm{Ca}^{2+}$-permeable and $\mathrm{Ca}^{2+}$-impermeable receptors in the same cells has been previously described when GluR2 is coexpressed with GluR4 (Burnashev et al., 1992b). In the glia studied here, the majority of receptors appear to be of the type that are impermeable to divalent cations and presumably contain GluR2 (edited). This would explain the small KA-induced $\mathrm{Ca}^{2+}$ current measured electrophysiologically, as most of the receptors containing GluR2 would be monovalent permeable and have low divalent permeability. On the other hand, the cells also seem to possess a smaller population of receptors that are $\mathrm{Ca}^{2+}$ permeable, presumably made up of combinations of glutamate receptor subunits not including GluR2 (e.g., GluR 1, $-\mathbf{3}$, -4 , or -6 ), or conceivably GluR2 in its unedited form. This is also suggested by the KA-induced $\mathrm{Co}^{2+}$ uptake studies, as $\mathrm{Co}^{2+}$ is presumably entering the cells via these receptors (Pruss et al., 1991; Fulton et al., 1992). It seems unlikely that all of the $\mathrm{Ca}^{21}$ influx observed could be due to a limited divalent cation permeability through a single population of GluR2-containing receptors, given the wide range of reversal potentials measured in $\mathrm{Na}^{+}$-free solutions. However, it is possible that there is some limited $\mathrm{Ca}^{2+}$ permeability through " $\mathrm{Ca}^{2+}$-impermeable" receptors (see Schneggenburger et al., 1993). Differences in $\mathrm{Ca}^{2+}$ buffering may also play a role, since a cell with exceptional $\mathrm{Ca}^{2+}$ buffering may require many divalent cation-permeable receptors in ordcr to show a large $\left[\mathrm{Ca}^{2+}\right]$ rise, while a cell with less $\mathrm{Ca}^{2+}$ buffering may show a large $\left[\mathrm{Ca}^{2+}\right]_{i}$ rise with only limited $\mathrm{Ca}^{2+}$ influx through a small number of permeable receptors. Whatever the situation, the $\mathrm{Ca}^{2+}$ flux is sufficient to produce a substantial increase in $\left[\mathrm{Ca}^{2+}\right]_{i}$ in cortical glial cells. It should be noted that our results are consistent with other recent reports showing that O2-A progenitor cells and cell lines derived from them possess both AMPA- and KA-selective glutamate receptors (e.g., GluR6) (Gallo et al., 1992, 1993). As the latter receptors desensitize very rapidly (and are not sensitive to cyclothiazide; Patneau et al., 1992; Wong and Mayer, 1993), we would not have detected them in our electrophysiological experiments.

The reason for the presence of glutamate receptors on some types of glial cells is not known. Potentially, they could exist to mediate interglia cell-signaling events. It has been shown that waves of $\left[\mathrm{Ca}^{2+}\right]_{i}$ occur in glial cultures following glutamate receptor activation (Cornell-Bell et al., 1990a; Glaum et al., 1990). Alternatively, neuron-glial communication could be mediated by these receptors as suggested by the results of Dani et al. (1992), perhaps utilizing diffusible messengers such as NO (Murphy et al., 1993). Studies showing that glutamate receptor agonists stimulate reactive gliosis in the CNS (DiChiara et al., 1980) also suggest that glial glutamate receptors may play a role in neuropathological events. Glutamate could also serve as a stimulus for the alteration of glial morphology, as suggested by the results of Cornell-Bell et al. (1990b), who demonstrated that glutamate could stimulate filopodia formation in hippocampal astrocytes. Finally, activation of glial metabotropic receptors has been recently shown to regulate glial $\mathrm{K}^{+}$conductances (Schwartz, 1993). Such findings suggest that glutamate may have multiple roles in the control of glial cell function in the brain.

\section{References}

Abe J, Sugihara H, Nawa H, Shigemoto R, Mizuno N, Nakanishi S (1992) Molecular characterization of a novel metabotropic glutamate receptor mGluR5 coupled to inositol phosphate/ $\mathrm{Ca}^{2+}$ signal transduction. J Biol Chem 267:13361-13368.

Ahmed 7, Lewis CA, Faber DS (1990) Glutamate stimulates release of $\mathrm{Ca}^{2+}$ from internal stores in astroglia. Brain Res 516:165-169.

Backus KH, Kettenmann H, Schachner M (1989) Pharmacological characterization of glutamate receptor in cultured astrocytes. J Neurosci Res 22:274-282.

Barry J de, Ogura A, Kudo Y (1991) $\mathrm{Ca}^{2+}$ mobilization in cultured rat cerebellar cells: astrocytes are activated by $t$-ACPD. Eur J Neurosci 3:1146-1154.

Berger T, Waltz W, Schnitzer J, Kettenmann H (1992) GABA- and glutamate-activated currents in glial cells of the mouse corpus callosum slice. J Neurosci Res 31:21-27.

Blankenfeld GV, Kettenmann H (1991) Glutamate and GABA receptors in vertebrate glial cells. Mol Neurobiol 5:31-43.

Blankenfeld GV, Verkhratsky AN, Kettenmann H (1992) $\mathrm{Ca}^{2+}$ channel expression in the oligodendrocyte lineage. Eur J Neurosci 4:10351048 .

Bowman CL, Kimelberg HK (1984) Excitatory amino acids directly depolarize rat brain astrocytes in primary cultures. Nature 311:656659.

Brorson JR, Bleakman D, Gibbons SJ, Miller RJ (1991) The properties of intracellular $\mathrm{Ca}^{2+}$ stores in cultured rat cerebellar neurons. J Neurosci 11:4024-4043.

Burnashev N, Khodorova A, Jonas P, Helm PJ, Wisden W, Monyer H, Seeburg PH, Sakmann B (1992a) Calcium-permeable AMPAkainate receptors in fusiform cerebellar glial cells. Science 256:15661570 .

Burnashev N, Monyer H, Seeburg PH, Sakmann B (1992b) Divalent ion permeability is dominated by the edited form of a single subunit. Neuron 8:189-198.

Byron KB, Villereal M (1989) Mitogen-induced $\left[\mathrm{Ca}^{2+}\right]_{i}$ changes in individual human fibroblasts. Image analysis reveals asynchronous responses which are characteristic for different mitogens. J Biol Chem 264:18234-18239.

Clark B, Mobbs P (1992) Transmitter-operated channels in rabbit retinal astrocytes studicd in situ by whole-cell patch clamping. J Neurosci 12:664-673.

Cornell-Bell AH, Finkbeiner SM, Cooper MS, Smith SJ (1990a) Glu- 
tamate induces calcium waves in cultured astrocytes: long-range glial signalling. Science 247:470-473.

Cornell-Bell AH, Thomas PG, Smith SJ (1990b) The excitatory neurotransmitter glutamate causes filopodia formation in cultured hippocampal astrocytes. Glia 3:322-334.

Dani JW, Chernjavsky A, Smith SJ (1992) Neuronal activity triggers calcium waves in hippocampal astrocyte networks. Neuron 8:429440.

DiChiara G, Morelli M, Porceddu ML, Mulas M, DelFiacco M (1980) Effect of discrete kainic acid-induced lesions of corpus caudatus and globus pallidus on glutamic acid decarboxylase of rat substantia nigra. Brain Res 189:193-208.

Egebjerg J, Heinemann SF (1993) $\mathrm{Ca}^{2}$ permeability of unedited and edited versions of the kainate selective glutamate receptor GluR6. Proc Natl Acad Sci USA 90:755-759.

Enkvist MOK, Holopainen 1, Akerman KEO (1989) Glutamate receptor-linked changes in membrane potential and intracellular $\mathrm{Ca}^{2+}$ in primary rat astrocytes. Glia 2:397-402.

Fok-Seang J, Miller RH (1992) Astrocyte precursors in neonatal rat spinal cord cultures. J Neurosci 12:275l-2764.

Fulton BP, Bume JF, RaffMC. (1992) Visualization of O-2A progenitor cells in developing and adult rat optic nerve by quisqualate stimulated cobalt uptake. J Neurosci 12:4816-4833.

Gallo V, Patneau DK, Mayer ML (1992) Expression of unique AMPA/ kainate receptor channels in glial precursor cells. Soc Neurosci Abstr 18:653.

Gallo V, Patneau D, Mayer M. Vaccarino F, Curtis J, Russell J (1993) Glutamate receptors in glial progenitor cells. J Neurochem [Suppl] 61:S259.

Glaum SG, Holzwarth JA, Miller RJ (1990) Glutamate receptors activate $\mathrm{Ca}^{2+}$ mobilization and $\mathrm{Ca}^{2+}$ influx into astrocytes. Proc Natl Acad Sci USA 87:3454-3458.

Grocs TJ, Penke B, Boti Z, Katarova Z, Hamori J (1993) Immunohistochemical visualization of a metabotropic glutamate receptor. Neuroreport 4:283-286

Hagiwara S, Byerly L (1981) Calcium channels. Annu Rev Neurosci 4:69-127.

Henneberry RC (1992) Cloning of the genes for excitatory amino acid receptors. Bioessays 14:465-471.

Hollmann M, Hartley M, Heinemann SF (1991) $\mathrm{Ca}^{2+}$ permeability of KA-AMPA-gated glutamate receptor channels depends on subunit composition. Science 252:851-853.

Holzwarth JA, Glaum SR, Miller RJ (1992) Activation of endothelin receptors by sarafotoxin regulates $\mathrm{Ca}^{2+}$ homeostasis in cerebellar astrocytes. Glia 5:239-250.

lino M, Ozawa S, Tsuzuki K (1990) Permeation of calcium through excitatory amino acid receptor channels in cultured rat hippocampal neurones. J Physiol (Lond) 424:151-165.

Inesi G, Sagara Y (1992) Thapsigargin, a high affinity and global inhibitor of intracellular $\mathrm{Ca}^{2+}$ transport ATPases. Arch Biochem Biophys 298:313-317.

Jensen AM, Chiu SY (1990) Fluorescence measurement of changes in $\left[\mathrm{Ca}^{2+}\right]$, induced by excitatory amino acids in cultured cortical astrocytes. J Neurosci 10:1165-1175.

Jensen AM, Chiu SY (1991) Differential intracellular calcium responses to glutamate in type 1 and type 2 cultured brain astrocytes. J Neurosci 11:1674-1684.

Jensen AM, Chiu SY (1993) Expression of glutamate receptor genes in white matter: developing and adult rat optic nerve. J Neurosci 13: $1664-1675$.

Matute C, Arellano RO, Conde-Gulni B, Miledi R (1993) mRNA coding for neurotransmitter receptors in a human astrocytoma. Proc Natl Acad Sci USA 89:3399-3403.

Mayer ML, Miller RJ (1990) Excitatory amino acids, second messengers and regulation of intracellular $\mathrm{Ca}^{2+}$ in mammalian neurons. Trends Pharmacol Sci 11:254-260.

Mayer ML, Westbrook GL (1987) Permeation and block of $N$-methylD-aspartate acid receptor channels by divalent cations in mouse cultured central neurons. J Physiol (Lond) 394:501-527.

Milani D, Facci L, Guidolin D, Leon A, Skaper SD (1989) Activation of polyphosphoinositide metabolism as a signal-transducing system coupled to excitatory amino acid receptors in astroglial cells. Glia 2:161-169.

Miller RJ (1991a) The revenge of the kainate receptor. Trends Neurosci $14: 477-479$
Miller RJ (1991b) Metabotropic excitatory amino acid receptors reveal their true colors. Trends Pharmacol Sci 12:365-367.

Miller RJ (1991c) The control of neuronal $\mathrm{Ca}^{2+}$ homeostasis. Prog Neurobiol 37:255-285.

Miller S, Bridges RJ, Cotman CW (1993) Stimulation of phosphoinositide hydrolysis by $\operatorname{trans}( \pm)$-ACPD is greatly enhanced when astrocytes are cultured in a serum free defined medium. Brain Res 618: $175-178$

Müller T, Moller T, Berger T, Schnitzer J, Kettenmann H (1992) Calcium cntry through kainate receptors and resulting potassium-channel blockade in Bergmann glial cells. Science 256:1563-1566.

Murphy S, Simmons ML, Agullo L, Garcia A, Feinstein DL, Galea E, Reis DJ, Minc-Golomb D, Schwartz JP (1993) Synthesis of nitric oxide in CNS glial cells. Trends Neurosci 16:323-328.

Patneau DK, Vycklicky L Jr, Mayer ML (1992) Cyclothiazide modulates excitatory synaptic transmission and AMPA/KA receptor desensitization in hippocampal cultures. Soc Neurosci Abstr 18:248.

Pruss RM, Akeson RL, Racke MM, Wilburn JL (1991) Agonist-activated cobalt uptake identifies divalent cation-permeable kainate receptors on neurons and glial cells. Neuron 7:509-518.

Raff MC, Abney FR, Cohen J, I indsay R, Noble M (1983a) Two types of astrocytes in cultures of developing rat white matter: differences in morphology, surface gangliosides, and growth characteristics. J Neurosci 3:1289-1300.

Raff MC, Miller RH, Noble M (1983b) A glial progenitor cell that develops in vitro into an astrocyte or an oligodendrocyte depending un culture medium. Nature 303:390-396.

Ranson PA, Thomas WE (1991) Pinocytosis as a select marker of ramified microglia in vivo and in vitro. $\mathrm{J}$ Histochem Cytochem 39: 853-858.

Rappolee DA, Wang A, Mark D, Werb Z (1989) Novel method for studying mRNA phenotypes in single or small numbers of cells. J Cell Biochem 39:1-11.

Robinson A, White T, Mason D (1986) Macrophage heterogeneity in the rat as delineated by two monoclonal antibodies MRC OX-41 and MRC OX-42, the latter recognizing complement receptor type 3. Immunology 57:239-248.

Schneggenburger R, Zhou Z, Konnerth A, Neher E (1993) Fractional contribution of calcium to the cation current through glutamate receptor channels. Neuron 11:133-143.

Schoepp DD, Conn PJ (1993) Metabotropic glutamate recepturs in brain function and pathology. Trends Pharmacol Sci 14:13-20.

Schwartz EA (1993) L-Glutamate conditionally modulates the $\mathrm{K}^{+}$current of Müller glial cells. Neuron 10:1141-1149.

Shigemoto R (1993) Morphological analysis of metabotropic glutamate receptor subtypes. J Neurochem [Suppl] 61:S262.

Sontheimer H, Kettenmann H, Backus KH, Schachner M (1988) Glutamate opens $\mathrm{Na}^{+} / \mathrm{K}^{+}$channels in cultured astrocytes. Glia 1:328336.

Stephens GJ, Djamgoz MBA, Wilkin GP (1993) A patch clamp study of excitatory amino acid effects on cortical astrocyte subtypes in culture. Recept Channels 1:39-52.

Tanabe $Y$, Nomura A, Masu M, Shigemoto R, Mizuno N, Nakanishi S (1993) Signal transduction, pharmacological properties and expression patterns of two rat metabotropic glutamate receptors mGluR3 and mGluR4. J Neurosci 13:1372-1378.

Thayer SA, Sturek M, Miller RJ (1988) Measurement of neuronal $\mathrm{Ca}^{2+}$ transients using simultaneous microfluorimetry and electrophysiology. Pfluegers Arch 412:216-223.

Usowicz MM, Gallo V, Cull-Candy SG (1989) Multiple conductance channels in type 2 astrocytes activated by excitatory amino acids. Nature 339:380-383.

Wong LA, Mayer ML (1993) Differential modulation by cyclothiazide and concanavalin A of desensitization at AMPA and kainate preferring glutamate receptors. Mol Pharmacol 44:504-510.

Wyllie DJA, Cull-Candy SG (1991) Calcium permeability of glutamate receptor channels in rat cerebellar granule cells and type 2 astrocytes in explant culture. J Physiol (Lond) 446:598P

Wyllie DJA, Mathie A, Symonds CJ, Cull-Candy SG (1991) Activation of glutamate receptors and glutamate uptake in identified macroglial cells in rat cerebellar cultures. J Physiol (Lond) 432:235-258.

Yuzaki M, Mikoshiba K (1992) Pharmacological and immunocytochemical characteristics of metabotropic glutamate receptors in cultured Purkinje cells. J Neurosci 12:4253-4263. 